NBER WORKING PAPER SERIES

\title{
SPURRING JOB CREATION IN RESPONSE TO SEVERE RECESSIONS: RECONSIDERING HIRING CREDITS
}

\author{
David Neumark \\ Working Paper 16866 \\ http://www.nber.org/papers/w16866 \\ NATIONAL BUREAU OF ECONOMIC RESEARCH \\ 1050 Massachusetts Avenue \\ Cambridge, MA 02138 \\ March 2011
}

This paper was previously circulated as "Policies to Encourage Job Creation: Hiring Credits vs. Worker Subsidies." I am grateful to Marisol Cuellar Mejia for outstanding research assistance and to Timothy Bartik, Doug Besharov, Vera Brusentsev, Karen Chapple, David Crane, John Laird, Marisol Cuellar Mejia, Carolyn Danielson, Hans Johnson, Jed Kolko, Wayne Vroman, and anonymous referees for helpful comments and discussions. This research was initiated when the author was a Bren Fellow at the Public Policy Institute of California, supported in part by the Donald Bren Foundation. But the views are solely those of the author. The views in this article do not reflect those of the Public Policy Institute of California or the National Bureau of Economic Research.

NBER working papers are circulated for discussion and comment purposes. They have not been peerreviewed or been subject to the review by the NBER Board of Directors that accompanies official NBER publications.

(C) 2011 by David Neumark. All rights reserved. Short sections of text, not to exceed two paragraphs, may be quoted without explicit permission provided that full credit, including $(\mathbb{C}$ notice, is given to the source. 
Spurring Job Creation in Response to Severe Recessions: Reconsidering Hiring Credits David Neumark

NBER Working Paper No. 16866

March 2011, Revised August 2012

JEL No. J08,J2,J78

\begin{abstract}
$\underline{\text { ABSTRACT }}$
The continuing adverse labor market effects of the Great Recession have intensified interest in policy efforts to spur job creation. In periods when labor demand and supply are in balance, either hiring credits or worker subsidies can be used to boost employment - hiring credits by reducing labor costs for employers, and worker subsidies by raising the economic returns to work. Historically, both types of policies have been used in pursuit of distributional goals as well, with hiring credits targeting employment of disadvantaged workers, and worker subsidies targeting low-income families. Hiring credits targeting the disadvantaged have generally been regarded as ineffective at both creating jobs and increasing incomes of low-income families, whereas worker subsidies have been viewed as more successful at both. However, in the context of the Great Recession - and severe recessions more generally - hiring credits may be particularly effective at spurring job creation, but only if they are designed quite differently from past hiring credits targeting the disadvantaged. Moreover, establishing a national hiring credit that kicks in during and after recessions may be an effective countercyclical measure - a useful addition to the "automatic stabilizers" already in place, and one that specifically targets job creation.
\end{abstract}

\author{
David Neumark \\ Department of Economics \\ University of California at Irvine \\ 3151 Social Science Plaza \\ Irvine, CA 92697 \\ and NBER \\ dneumark@uci.edu
}




\section{Employment Problems in the Short Term and the Longer Term, and Possible Policy Responses}

The adverse effects of the Great Recession on U.S. labor markets are hardly news. Figure 1 shows the decline in job creation (net job growth) beginning in 2006 followed by sharp declines in jobs in 2008 and 2009, and the corresponding dramatic changes in unemployment rates. The continued stagnation of job growth since the Great Recession formally ended has made "job creation" the prevailing mantra in both Washington, DC, and state capitals.

This paper considers policies that could be used to boost job growth during and after a severe recession by changing labor demand incentives for employers or labor supply incentives for workers. Specifically, the paper focuses on subsidies to employers to hire workers ("hiring credits"), and subsidies to individuals to enter the labor market ("worker subsidies," in the form of the Earned Income Tax Credit, or EITC, in the United States). Both types of policies have been used extensively in the past, at both the federal and state level, although a central motivation of hiring credits targeting the disadvantaged can also be viewed as redistributing jobs, and the EITC has the explicit distributional goal - quite distinct from job creation - of increasing incomes of low-income families.

Viewed as job creation policies, most of the existing research literature fails to provide support for the use of hiring credits. Hiring credits have numerous problems, including stigmatizing eligible workers and low participation by firms - which substantially reduce or eliminate employment effects not to mention poor targeting of low-income families. In contrast, the EITC, aside from achieving its distributional goals, is more effective at increasing employment among affected groups and overall (Dickert-Conlin and Holtz-Eakin, 2000).

The negative conclusions about hiring credits, which are echoed in standard labor economics textbooks (e.g., Borjas, 2010, and Ehrenberg and Smith, 2009) as well as recent research (Hamersma, 2005, 2008, 2011), might suggest that hiring credits are not a useful response to the Great Recession or future recessions: If hiring credits fail even at boosting relative employment of targeted groups, how can they increase aggregate employment? And how can they achieve a secondary goal of hiring credits in the current context - helping lower-income families weather the recovery from the Great Recession? 
However, this negative assessment of hiring credits is based on evaluations of credits targeting the disadvantaged. Drawing on other evidence, this paper argues that hiring credits can be much more effective at countering the kind of stagnant employment growth experienced in the recovery from the Great Recession. In particular, a broadly-based hiring credit that does not specifically target the disadvantaged could avoid many of the problems with hiring credits, and prove effective at creating jobs. Moreover, during recovery from the Great Recession and other severe recessions, expansions of worker subsidies are unlikely to do much to spur job creation, insofar as these recessions are characterized by deficient demand for labor. Thus, reconsidering the broader body of evidence, and placing potential policies in the appropriate macroeconomic context, suggests that hiring credits, if well-designed, can be effective at helping spur job creation in the recovery from the Great Recession, and also at mitigating the effects of future severe recessions.

\section{How to Evaluate Job Creation Policies}

For the purposes of evaluating job creation policies to recover from the Great Recession, ${ }^{1}$ the alternative job creation policies should be evaluated based on - first and foremost - the net cost per job created, taking account of direct and indirect costs and benefits. Because these policies are potentially plagued by large inefficiencies with respect to net job creation, and there may be a variety of longer-term benefits of employment, estimation of these costs and benefits is difficult and entails some guesswork. But there is research that provides information on plausible ranges of costs, and that identifies some ways to make the policies more cost effective.

Evaluation criteria besides cost also come into play. One is the strength of the evidence for job creation effects of alternative policies; if the evidence on the effects of a particular policy is less compelling, the case for that policy must be viewed as weaker. A second is distributional effects. Although the evaluation of policies on distributional grounds is subjective (for an economist, dependent on the social welfare function), at a minimum the distributional effects and tradeoffs need to be elucidated for policy decisionmaking, and in some cases there may be broad agreement on the intended beneficiaries

\footnotetext{
${ }^{1}$ Much of the discussion from here refers specifically to the Great Recession, but the general issues raised would carry over to future severe recessions, insofar as they are primarily demand driven.
} 
of policy.

Finally, the details of implementation introduce an added layer of uncertainty - in particular whether policy goals and hence effectiveness are likely to be undermined by individual behavioral responses (e.g., unintended consequences or fraudulent abuse of a program) or political pressure. Anticipating whether the effectiveness of a policy is likely to be undermined and what might be done to avoid this is also important in choosing among and designing policies. After outlining the scope of the analysis this paper presents, each of these issues bearing on the evaluation of hiring credits and worker subsidies is discussed in the sections that follow.

\section{Hiring Credits, Worker Subsidies, and Alternative Policies}

The job losses experienced during the Great Recession, and the stagnant recovery, have led to a wide variety of policies - some enacted, and others proposed - to encourage short-term job creation. At the federal level, the principal tools have been stimulative fiscal and monetary policy. And at the state level the list is almost endless. Just in one state (California), for example, proposals include sales and use tax exemptions for manufacturing, tax reductions for small businesses, corporate tax reductions and reforms, tax credits for costs of job training and education, a research and development tax credit, mandated economic impact analysis of new regulations, regulatory reform, caps on compensatory damages, a homebuyer tax credit, reducing the capital gains tax, lowering sales tax for new cars, state tax deductions for Health Saving Accounts, barriers to establishing cap-and-trade to implement climatechange legislation, creation of another state enterprise zone, repeal of penalties for corporations that understate tax liabilities, allowing sale of out-of-state health plans, development of High Speed Rail, expedited public school construction, distributing federal transportation funds for "shovel ready" projects, promotion of in-state renewable energy resources, and repairs of levees and other flood control investments. $^{2}$

The analysis in this paper focuses instead on policies that directly change labor demand or labor

\footnotetext{
${ }^{2}$ See http://arc.asm.ca.gov/cajobs/?p=solutions, http://cssrc.us/publications.aspx?id=7554, http://senweb03.sen. ca.gov/focus/agenda2010/legislation.aspx, and http://www.calchamber.com/governmentrelations/pages/jobcreators.aspx (viewed July 29, 2010).
} 
supply incentives to try to create jobs. In contrast, the policies listed above are likely to deliver only second-order effects, because they do not directly change the labor demand incentives of firms or the labor supply incentives of workers. For example, policies such as enterprise zones target employment growth in particular locations, and thus may act largely to substitute employment in one place for employment in another, or to lead employers to substitute employees eligible for the credit for those who are not (Neumark and Kolko, 2010). Policies that subsidize other business activities, such as investment in machinery, may lead firms to substitute away from labor by lowering the relative price of capital. Policies that favor particular industries may be more reflective of political influence than job creation potential. And policies that favor businesses generally - such as reducing taxes or regulatory costs should help those businesses become more profitable and expand their workforces; but because such policies do not necessarily reduce the relative price of labor, the cost per job created may be quite high.

One potential job creation policy that has received little attention, and correspondingly is not emphasized in this paper, is increases in public employment - direct job creation by the government. There is a history with such programs in the United States, including both countercyclical efforts - most notably the Works Project Administration (WPA) during the Great Depression - and, more recently, efforts targeting the disadvantaged - such as the Comprehensive Employment and Training Act (CETA), which was in effect from 1974 through 1982. Currently, there are two types of public employment programs in the United States: youth summer employment programs, sometimes funded by federal grants (such as the Summer Youth Employment Program funded by the American Recovery and Reinvestment Act, or ARRA); and community-service jobs that are funded and required as part of welfare reform, such as Wisconsin's W-2 program. ${ }^{3}$

Public employment could be quite expensive relative to hiring credits and worker subsidies. The latter policies try to spur job creation or increase employment by changing the marginal cost or benefit of work, whereas public employment requires paying the entire cost of employing the worker. This may well explain why there is essentially no movement toward creating publicly-funded jobs to help with

\footnotetext{
${ }^{3}$ See http://dcf.wisconsin.gov/w2/wisworks.htm (viewed August 2, 2010).
} 
recovery from the Great Recession, with the exception of youth programs. ${ }^{4}$ On the other hand, as discussed below, it is hard to design hiring credits or worker subsidies that pay only for the increment to hiring, so the cost comparison with public employment may turn out to be less favorable than it might appear at first blush. Moreover, the estimates of the cost of job creation via ARRA, as discussed below, are very high. A final reservation about public employment that has been raised previously is the potentially low value of the output (Bishop and Haveman, 1978), although it is not necessarily the case that public employment would create less valuable output than other government spending. In contrast, incentivizing private-sector hiring should increase derived demand for labor that produces output that is valued in the market.

Fairly recent and extensive reviews of public-service employment in the United States are provided by Bartik (2001) and Ellwood and Welty (2000). These reviews argue that public-service employment programs have more merit than commonly thought. They argue, in particular, that: the jobs are not strict "make-work" but produce services that are valued; the programs do displace some publicsector workers, but if well-designed this displacement effect can be kept to around 25 percent; administrative costs and barriers are not overwhelming, citing rapid start-up and job creation of some past programs $;{ }^{5}$ and there is little evidence of private-sector crowd-out through competition for workers. However, there are also some important cautions; in particular, there are examples of public-service employment programs that were "wasteful, inefficient, displacing, and counterproductive" (Ellwood and Welty, 2000, p. 300). ${ }^{6}$

\footnotetext{
${ }^{4}$ Nonetheless, a prominent economist has called for just such a response (Schiller, 2010).

${ }^{5}$ The reviews disagree on some of the specifics regarding this issue. Bartik notes that politics may delay job creation through these programs, and specifically cites the fact that CETA started in 1974, but did not reach peak public employment until 1978, "well after employment growth and economic growth had resumed" (p. 177). On the other hand, referring to the same program, Ellwood and Welty conclude that "There is some evidence from the recession of 1975 that countercyclical programs can come up to speed quickly" (p. 348). These differing assessments appear to be mainly different subjective views of the same evidence.

${ }^{6}$ Finally, Lower-Basch (2011) describes subsidized job programs using money from the TANF Emergency Fund created as part of ARRA. Many states (39, plus the District of Columbia) used these to heavily subsidize jobs sometimes up to 100 percent for several months - mainly with private employers. These subsidies targeted lowincome people. There is not really evidence regarding longer-term employment effects, but Lower-Basch argues that these kinds of subsidies "can help severely disadvantaged workers stay economically active" (p. 7). Although one might view these kinds of job subsidies as a private-sector substitute for public employment, Lower-Basch focuses on them as an alternative to the WOTC hiring credit.
} 
In focusing on hiring credits and worker subsidies, the intention is not to argue that public employment should necessarily be dismissed. Rather, the focus is on hiring credits and worker subsidies because, given the widespread concerns about increasing public employment, and severe constraints on the ability of the federal government to engage in major new spending, using public employment to help with recovery from the Great Recession is almost surely politically infeasible. ${ }^{7}$ More generally, this paper is not intended to be a comprehensive survey or analysis of all policies that could potentially spur job creation; that would be the task of many papers covering a far wider number of topics. Rather, it focuses more narrowly on policies that directly affect incentives to hire or to work, and in particular emphasizes the potential value of hiring credits - properly designed and implemented - in countering the effects of the Great Recession.

There may also be alternative policies that lower other costs associated with the employment of workers - such as taxes on labor, labor market regulations, or minimum wages. Such policy changes might be expected to have effects in the same direction as hiring or worker subsidies. However, their effects on job creation would likely be more muted. Reducing taxes on labor generally will reward businesses even if they do not expand employment. Relaxing labor market regulations will not necessarily increase employment. ${ }^{8}$ And minimum wages do not affect many workers.

Finally, to put this policy analysis in perspective, the comparison of hiring credits and worker subsidies that this paper presents is not a direct response to alternative policy proposals to use these two policies to spur job creation during recovery from the Great Recession. Short-term proposals emphasizing job creation have focused more on hiring credits, ${ }^{9}$ whereas calls for an expanded EITC have emphasized either the extra income a more generous EITC can provide to families suffering from the

\footnotetext{
${ }^{7}$ One could argue, though, that the willingness to engage in "tax expenditures" through lowering taxes or providing credits, but the unwillingness to increase direct government expenditures, is difficult to rationalize.

${ }^{8}$ In some cases this can have the opposite effect, depending on whether the regulation affects fixed or variable costs. For example, a lower overtime premium reduces employment as long as the elasticity of the demand for labor (with respect to the wage) is less than one in absolute value, which is the consensus in the empirical literature (Hamermesh, 1993); see Cahuc and Zylberberg (2004, Chapter 4).

${ }^{9}$ Most recently, there is a hiring credit for the long-term unemployed in President Obama's proposed American Job Act (http://www.whitehouse.gov/the-press-office/2011/09/08/fact-sheet-american-jobs-act, viewed May 11, 2012).
} 
Great Recession (e.g., National Community Tax Coalition, 2010), ${ }^{10}$ or the longer-employment run problems for the disadvantaged that they might help address (e.g., Edelman et al., 2009).

However, because the existing research literature provides a negative assessment of hiring credits, but a much more positive assessment of worker subsidies, it is useful to reconsider this prevailing view in the context of the Great Recession. In contrast with the existing assessments of these alternative policies, this paper argues that during recovery from the Great Recession, a hiring credit targeting job creation generally, and with other specific elements discussed below, could be particularly effective at spurring job creation in the short run, while worker subsidies are unlikely to prove useful. Moreover, the same is likely to be true in countering future severe recessions.

\section{Evaluating Hiring Credits and Worker Subsidies as Job Creation Policies}

\section{IV.A. Theory}

Economic theory demonstrates that, in principle, employment can be increased by either subsidizing employers (with a hiring credit) or employees (through an EITC or other worker subsidy). The effects of a hiring credit are depicted in Panel A of Figure 2. Because a hiring credit reduces the effective wage paid by employers, the credit will shift the labor demand curve up and increase employment. In the figure, the hiring credit (c) shifts the demand curve to D', so employment increases from $\mathrm{E}$ to E'. ${ }^{11}$ The wage paid to workers increases from w to w', although the wage cost of labor to employers declines to $\mathrm{w}^{\prime}(1-\mathrm{c})$.

Figure 3 instead illustrates a worker subsidy (e). In this case labor supply shifts out from entry of workers into the labor market, resulting in an increase in employment from E to E', The market wage paid by employers fall from w to w', but workers earn a higher wage because they get w' plus the

\footnotetext{
${ }^{10}$ In fact the ARRA temporarily raised the EITC for families with three or more children, with the goal of helping working families, rather than encouraging employment (http://www.irs.gov/newsroom/article/0,,id=205666,00.html http://www.cbpp.org/cms/index.cfm?fa=view\&id=3361, and http://www.whitehouse.gov/assets/documents/staff_report_ARRA-FINAL.pdf, viewed October 5, 2011), ${ }^{11}$ Note that the figure simplifies in that the hiring credit pays a constant percentage of the wage, rather than, as is more common, some percentage of wages paid to a worker up to a certain amount. A similar simplifying assumption is made regarding worker subsidies. Note also that, as the label on the horizontal axis indicates, the figure (and later figures) are drawn for the level of employment, instead of hours. The figure could represent either, but depicts employment effects because hiring credits are usually focused on the number of workers employed (although, as discussed below, the hiring credit in the American Jobs Act proposed by President Obama would reward payroll increases through higher employment, hours, or wages).
} 
subsidy, or, in the figure, a wage of w' $(1+e)$. The graph makes clear that both policies are predicted to increase employment. Moreover, there are values of e and c that can be chosen such that, at least in this simple, stylized case, the quantitative effects on employment (and wages) of hiring credits and worker subsidies are equal.

\section{IV.B. Macroeconomic Considerations}

The economic story described above, as the figures indicate, pertains to labor markets initially at equilibrium (and moving to a new equilibrium). But most economists view severe recessions like the Great Recession as periods when the (aggregate) labor market is not in equilibrium because demand has fallen and wages are downwardly rigid, for the simple reason that if labor markets clear like other markets, then it is hard to explain why we end up with high unemployment, rather than having wages get bid down to clear the labor market owing to the pressure of workers competing for jobs.

The question of the nature of economic recessions is a deep and long-standing question in macroeconomics. Putting things (too) simply, one view is that even though in a period like the current one, unemployment is very high, labor markets are in fact in equilibrium. In much research the model corresponding to this view is one in which because of shocks that have hit the economy, worker productivity is sufficiently low that at the wages currently offered workers choose to be unemployed rather than to work (Lucas and Rapping, 1969). This requires interpreting measured unemployment as failing to capture employment prospects for workers at current wages given their skills. In this view, because the labor market is in equilibrium, policies that shift out the labor supply curve would increase employment. The more widely held view of recessions, however, is that they are caused when aggregate demand in the economy declines and short-run rigidities prevent wages from falling to clear the labor market.

In the case of the Great Recession, the productivity shock story fits the facts poorly, as productivity remained high during the recession and afterwards. ${ }^{12}$ In contrast, there is no doubt that the Great Recession was caused mainly by a large negative demand shock owing to the collapse of the

\footnotetext{
${ }^{12}$ See http://www.bls.gov/news.release/prod2.t07.htm (viewed August 18, 2011).
} 
housing market. In this case, where the labor market is at disequilibrium with deficient demand, pushing out the labor supply curve, as an EITC or other worker subsidy does, will do little to increase employment. ${ }^{13}$ This is made clear by reference to point $U$ in Figure 3, which is meant to depict a labor market in disequilibrium in which the wage is fixed at a value above its equilibrium level and labor supply exceeds demand. Because in this case employment is determined solely by the intersection of the labor demand curve and a horizontal line through the wage, shifting the labor supply curve - as a worker subsidy would do - does nothing to increase employment. In contrast, as reference to the same point $U$ in Figure 2 shows, hiring credits have their maximal effect in this case; equilibrium employment increases by the full horizontal shift of the demand curve, and increases to the greatest extent possible because wages do not get bid up from the increased demand for labor. ${ }^{14}$

Thus, macroeconomic considerations favor hiring credits over an expanded EITC as a policy for spurring job creation in the recovery from the Great Recession, and the same would apply to future recessions that are demand-driven. As a consequence, we next turn to a detailed discussion of hiring credits, before returning briefly to touch on related issues regarding worker subsidies.

\section{IV.C. Hiring Credits ${ }^{15}$}

In the United States, there is a long history of using hiring credits targeting hiring from specific disadvantaged groups. In the past, Job Opportunities in the Business Sector (JOBS) targeted hiring of

\footnotetext{
${ }^{13}$ Another way to think of this is that firms could hire all the workers they want at the going wage, because of excess supply, which implies that the supply of labor is infinitely elastic (perfectly horizontal) (Katz, 1998, p. 25), and when the supply curve is horizontal shifting it to the right has no effect on employment. This is strictly true in the simple supply and demand framework. But in other models a labor supply shift can have some effect. In an efficiency wage model, for example, higher labor supply will raise the unemployment rate, lowering the efficiency wage.

${ }^{14}$ One perspective that allows for some potential role for worker subsidies is that policy and other responses to the Great Recession contributed to the slow recovery by increasing the implicit taxation of income (Mulligan, forthcoming). Mulligan documents increases in eligibility for safety net programs during the Great Recession and increases in benefits available under these programs, as well as mortgage restructurings that are often tied to earnings. He argues that these raised the relative value of not working through higher implicit taxation of earnings, leading to labor supply reductions. Mulligan's view is strongly contested; for example, see http://krugman.blogs.nytimes.com/2011/08/13/the-general-theory-of-anti-mulliganism/ (viewed May 8, 2012.) Regardless, as long as deficient aggregate demand caused the Great Recession and continues to plague the recovery - even if it is no longer the only factor - then hiring credits would still be effective.

${ }^{15}$ When hiring credits are designed to encourage job creation - that is, net new hiring - they are sometimes referred to as "job creation tax credits." This paper uses the more generic label "hiring credit," but later on emphasizes the importance of designing hiring credits to encourage new hiring, rather than simply subsidizing hiring that would have occurred without the credit.
} 
young (and older) disadvantaged workers, and the Work Incentives Tax Credit (WINTC) targeted AFDC recipients. The Targeted Jobs Tax Credit (TJTC), in effect from 1979 through 1994, targeted these groups and others, before being replaced by the Work Opportunity Tax Credit (WOTC), which similarly targets multiple groups. Under the Job Training and Partnership Act (JTPA), temporary wage subsidies went to firms providing long-term employment for recipients of on-the-job training; this was the key wage subsidy for economically-disadvantaged adults who were not on welfare. JTPA was replaced by the Workforce Investment Act (WIA) in 2000, which does not include wage subsidies (except for some wage costs during training).

In contrast, hiring credits to counter the business cycle have been rarer. The federal New Jobs Tax Credit (NJTC) was enacted to counter the recession of the mid-1970s; it was unique among federal efforts in that it was "non-categorical" rather than targeting specific groups. ${ }^{16}$ The recently enacted Hiring Incentives to Restore Employment (HIRE) Act included an exemption from the employer's share of Social Security taxes due for March-December 2010, plus an additional $\$ 1,000$ credit per worker. The HIRE Act targets those entering employment from unemployment or out of the labor force. And the American Jobs Act (AJA) proposed in 2011 by Obama Administration would offer payroll tax exemptions for increments to payroll and a hiring credit for those unemployed more than six months.

Table 1 provides information on current federal hiring credit policies. There is also a wide variety of state hiring credit programs, and the table provides examples. Some (Florida and Maryland) focus on the unemployed, like the HIRE Act, while others couple hiring credits with requirements to invest in facilities (Delaware) or training (Iowa). Some states tie credit eligibility or amount to what the new jobs pay.

Predicted effects of hiring credits - theory and reality

Panel A of Figure 2 illustrated the theoretical prediction that a hiring credit increases employment by reducing the effective wage paid by employers. There are, however, important complicating factors. Dickert-Conlin and Holtz-Eakin (2000) incorporate these issues into the standard analysis to show how

\footnotetext{
${ }^{16}$ Still, the NJTC created stronger incentives to hire low-wage workers by applying only to the first $\$ 4,200$ of wages per employee (in 1977 and 1978).
} 
these complications can reduce - perhaps substantially - the incentive effects of hiring credits; see also Katz (1998). These complications stem from the two key issues that arise in designing hiring credits: creating incentives for employers to engage in net job creation; and targeting workers eligible for the credit.

To create the strongest incentives for employers to create jobs they would not otherwise have created, a hiring credit has to identify and reward net (positive) changes in employment that would not have occurred absent the credit. The potential problem is illustrated in Panel B of Figure 2. The employment gain from the hiring credit is E' - E. If the subsidy is paid only on the new employment generated by the hiring credit, then the subsidy cost is given by the rectangle B. But, at the other extreme, if the subsidy is paid on all employment, then there is an additional cost given by the rectangle A, which clearly can be far bigger. ${ }^{17}$ It might seem unreasonable to think about a hiring credit designed so poorly that it pays the credit for all workers employed prior to the implementation of the credit. However, this graph fails to capture the dynamics of employment. For a given level of employment there are always many accessions to jobs and separations from jobs - more so for the unskilled. Thus, even if a hiring credit succeeds in paying only for new hiring, a good deal of the credit could pay for hiring that occurs as firms simply maintain employment at their initial levels - that is, for gross rather than net job creation.

The literature on hiring credits makes clear that efforts to avoid payments for hiring that would have occurred anyway - referred to as "windfalls" for employers - are largely unsuccessful. Estimates of the amount of wastage, characterized as the share of credits paid for hiring that would have occurred even without the credit, are often well over 90 percent (Bartik, 2001).

Moreover, efforts to design hiring credits that reduce windfalls can lead to unintended consequences that undermine the job-creation goals of these credits. Paying credits only for new hires rather than net job growth can create incentives for churning employees, continually firing some and hiring others to collect more credits. Incentives for churning can be reduced by barring hiring credits to firms that do not retain subsidized workers, but the requisite record-keeping can pose large administrative

\footnotetext{
${ }^{17}$ And in reality B would be a much smaller fraction of A + B; in the figure the effect of the hiring credit is large for illustrative purposes.
} 
costs. ${ }^{18}$ An alternative approach is to estimate other determinants of employment growth, and pay the credit for net positive changes that would not have otherwise occurred. In principle this can eliminate incentives for churning and only pay for jobs created by the credit, but it imposes the need for a good deal of information from firms and accurate use of this information by administrators. Even then, this approach is subject to substantial error, it likely entails large administrative burdens on firms, and it could generate incentives for employment variation since increases are subsidized but reductions are not penalized.

For all of these reasons, concerns about windfalls tend to lead hiring credit policies to impose reporting requirements that are costly for firms. The administrative costs to firms of obtaining hiring credits for new workers effectively reduce the wage subsidy that the hiring credit generates, hence diminishing the impact of the wage subsidy and discouraging utilization of the credits.

Turning from the issue of incentives, the second issue that usually complicates the design of hiring credits is the targeting of specific groups of workers - for example, the targeting of disadvantaged workers by federal credits. The motivation for this targeting is twofold. First, hiring credits, like many other policies, often have distributional goals. And second, lower employment rates among less-skilled, disadvantaged workers often make them eligible for costly public benefits if non-employed. The cost of targeting, however, may be that workers who are eligible for hiring credits can become "stigmatized." Their eligibility can provide information to employers that they have been unsuccessful in the labor market, which can lead employers to regard eligible workers as risky or as less productive, offsetting the potential impact of the hiring credit.

\section{Evidence on effects of hiring credits}

Empirical research addresses the employment effects of hiring credits, as well as the distortions of firms' incentives they can induce, and administrative and stigma costs. Reflecting the predominant experience, most of this research focuses on credits targeting the disadvantaged. However, research on hiring credits used to counter the business cycle - in particular, the NJTC - may be more relevant in

\footnotetext{
${ }^{18}$ These and many other issues with the design of hiring credits are discussed in Bishop and Haveman (1979).
} 
thinking about policy responses to the Great Recession, and hence after a brief review of evidence on targeted hiring credits, the discussion focuses on studies of the NJTC.

Confirming concerns about low utilization because of administrative costs involved with claiming hiring credits, Katz (1998) emphasizes the small share of potential hiring credits claimed by employers under the JOBS and WINTC programs. Similarly, Hamersma (2005) estimates that for the WOTC and Welfare-to-Work (WtW) tax credits, national participation in 1999 among eligible workers was between 10 and 33 percent for welfare recipients and even lower for other groups.

Reflecting the problem of large windfalls, Lorenz (1995) suggests that a good deal of claiming of the TJTC was spurred by management assistance companies or consultants that helped employers file claims retroactively for workers they had hired. This does not necessarily imply that the credit was ineffective, as it may have spurred extra hiring even if the credit was not always claimed contemporaneously. But it is reasonable to interpret a high degree of retroactive claiming as reflecting substantial windfalls in the form of credits paid to employers who would also have engaged in hiring anyway.

There is also evidence suggesting that narrow targeting of hiring credits stigmatizes the intended beneficiaries, dissipating the effects of the credits. A striking example is an experimental program for welfare recipients in Dayton, Ohio, under the TJTC (Burtless, 1985). One group received vouchers that they could present to employers for direct cash rebate subsidies, a second group received vouchers that let employers claim hiring credits under one of two existing programs, and a third group was eligible for the same credits, but neither received vouchers to give to employers nor were they told that they were eligible. The third group had the most success in finding employment. Given that assignment to groups was random, so that the only difference was the information given to employers and workers, it is plausible to interpret the worse outcomes for those with vouchers as indicating adverse stigma effects that reduced the effect of the hiring credits.

Finally, evidence of positive employment effects is modest at best. The TJTC appears to have boosted employment of disadvantaged youths, but only modestly (Katz, 1998). Evidence from JTPA, 
which targeted economically-disadvantaged adults who were not eligible for the TJTC, indicates positive and persistent program impacts for adults (measured in terms of post-program earnings) when the program was combined with job search assistance, ${ }^{19}$ although no benefits for out-of-school disadvantaged youths (Bloom et al., 1994). Recent evidence from Wisconsin on the WOTC and WtW credits is more pessimistic (Hamersma, 2008). Employment effects are small or non-existent, and at best there are positive short-run effects but no longer-run effects.

A final criticism of hiring credits targeting disadvantaged, low-wage workers, is that they may do relatively little to increase incomes of low-income families. As Dickert-Conlin and Holtz-Eakin (2000) document, the overlap of low-wage workers with poor families is often rather weak, because there are many non-poor families with low-wage workers, and many poor families have no workers. ${ }^{20}$

The NJTC differed from most hiring credits in being non-categorical rather than targeting the disadvantaged. It was in effect only briefly, from mid-1977 to the end of 1978, to help spur recovery after the recession earlier in the 1970s (Katz, 1998). The NJTC relied on a simple way of rewarding hiring that would not have otherwise taken place, offering the credit to firms in which employment increased by more than two percent, and paying up to 50 percent of the first $\$ 4,200$ in wages per new hire, up to a maximum of $\$ 100,000$ per firm in a year. The broader nature of the NJTC is more similar to other credits recently used or proposed as countercyclical policy. For example, the recent federal HIRE Act was similarly non-categorical. And many state hiring credits adopted to help spur employment growth in the recovery from the Great Recession were either non-categorical or focused broadly on the unemployed.

In contrast to targeted hiring credits, the NJTC was likely to be claimed by employers; according to Bartik (2001, p. 210), under the WINTC program fewer than 15 percent of hires eligible for the credit resulted in the credit being claimed, vs. 50 percent for the NJTC. One possible explanation for the difference was that the WINTC program was aimed at disadvantaged workers, whereas the NJTC was not targeted at particular social or demographic groups and may therefore have entailed less administrative

\footnotetext{
${ }^{19}$ Bartik (2001, Ch. 1) suggests that other efforts in support of hiring credit programs may help overcome stigma effects by providing some information to employers that the workers are more productive than their "stigmatizing characteristics" might suggest.

${ }^{20}$ The WOTC may be better in this regard because it targets, in part, long-term TANF recipients.
} 
burden for employers.

Turning to the evidence on employment effects, Perloff and Wachter (1979) study variation in whether firms reported that they knew about the NJTC. They found that although one-third of all firms reported such knowledge, a much higher share of large firms did, and firms that knew about the NJTC had significantly higher employment growth. Their conclusions are (appropriately) cautious, because any inference comes from the relationship between employment growth and knowing about the credit, which is not random. Rather, it is conceivable that "firms with growing employment had a much greater incentive to learn about the program" (Katz, 1998, p. 31). On the other hand, the NJTC could have been more effective at larger firms because administrative costs are important, but have a large fixed component that can be spread over more workers at large firms.

Evidence from Bishop (1981) suggests that the NJTC increased employment in construction, trucking, retail trade, and wholesale trade by about 400,000 jobs, or about 0.5 percent of economy-wide employment, a sizable increase. Bishop suggests that these industries are particularly sensitive to hiring credits (or changes in input prices generally) because capital equipment depreciates quickly and labor turnover is high (p. 210), which is relevant to the Great Recession given that is was characterized by dramatic declines in construction employment. Bishop also uses knowledge about the NJTC as the "treatment" variable, but rather than individual firm-level variation, he studies a common variable applied to all firms that captures the time-series variation in the proportion of firms reporting knowledge of the NJTC. As such, the effect of the NJTC is hard to distinguish from other time-series changes, although an advantage of this approach is that the identifying information is less likely to be endogenously driven by which firms are growing.

Katz (1998) suggests that, overall, the evidence supports the conclusion that this kind of "temporary, noncategorical, incremental employment subsidy has some potential for stimulating employment growth" (p. 31). ${ }^{21}$ This echoes the cautious conclusions in the original papers. Perloff and Wachter (1979) conclude that "the New Jobs Tax Credit may have shifted the distribution of the rate of

\footnotetext{
${ }^{21}$ The term "employment subsidy" in this quote is the same as the term "hiring credit" used throughout this paper.
} 
growth of employment" (p. 178), but note that, because "most firms either did not know of the program or were not influenced by it," the short-run NJTC was "an imperfect countercyclical tool" (p. 179).

Similarly, Bishop (1981) notes that "Perhaps the NJTC variable is capturing other exogenous forces that are inducing contemporaneous employment increases ... in the sectors studied" so that "the conclusion that NJTC is having major effects on employment and prices must remain tentative until better data or more periods of observation become available" (p. 240).

Bishop (2008) and Bartik and Bishop (2009) interpret the evidence more strongly in advocating for a federal hiring credit to counter the Great Recession, arguing that "Tax credits for new jobs have been tried before, and they worked well" (Bartik and Bishop, 2009, p. 9), and that "the NJTC probably generated at least a million jobs by the end of 1978 " (Bishop, 2008, p. 5). ${ }^{22}$ Based on the evidence, however, the more cautious summary of the evidence along the line of Katz's is probably more defensible. ${ }^{23}$ Moreover, there is uncertainty in extrapolating to the present results from the NJTC, which was implemented over 30 years ago.

State hiring credits are less likely to target the disadvantaged. Most state hiring credits, in some form or another, try to ensure that the credits are paid for new job creation (see Table 2). For example, many states tie payment of the credit to the creation of new jobs (e.g., Colorado and Connecticut), and some have provisions to "recapture" some of the tax credit if net job creation falls below the job creation for which credits were received. Despite the plethora of state hiring credit programs, the existing research is nearly exclusively about federal programs. One exception is Bartik and Erickcek's (2010) evaluation of the MEGA Tax Credit Program in Michigan, which is quite different from the other hiring credits. Finally, a very recent paper (Chirinko and Wilson, 2010) estimates the effects of state hiring credits, finding some modest evidence of positive effects.

To summarize, the relatively pessimistic conclusions about the effectiveness of hiring credits apply to programs targeting the disadvantaged. There is reason to believe that more broadly-focused

\footnotetext{
${ }^{22}$ In this, they echo Hamermesh's earlier summary of the same evidence, concluding that "The evidence on the effect of the NJTC on employment growth is both positive and convincing" (1993, p. 192).

${ }^{23}$ Indeed, earlier they described the evidence more cautiously. Bishop's (1981) reservations were noted above. And Bartik (2001) wrote that "The NJTC may have created as many as 700,000 new jobs" (p. 226, emphasis added).
} 
hiring credits intended to counteract a severe recession may be more effective.

Costs of hiring credits per job created

Some of the costs of hiring credits are simple to calculate, such as the amount of hiring credits paid. Other components of costs are trickier to assess, such as the value of other public services that may be reduced if tax revenue is diverted to pay for hiring credits, or the costs of tax increases if these are used to finance the credits. The most difficult and substantively important part of the cost calculation - and one that cannot be avoided - is the estimate of how many jobs were created as a result of the credit, because this number, and not the number of jobs credited, is needed to estimate the cost per job created. Owing to these difficulties and others discussed below, estimates of the net costs of creating jobs via hiring credits have to be viewed as suggestive calculations rather than as rigorous evidence.

Even in the context of a very positive assessment of a hiring credit program in Michigan, Bartik and Erickcek (2010) estimate that the credit is decisive in 8 percent of cases, or that 92 percent of credits are paid for jobs that would have been created anyway. More typically, the authors suggest, the corresponding numbers are 4 and 96 percent. The implication is that we need to multiply the hiring credit cost per worker for whom a credit is claimed by 12.5 to 25 (using the 8 percent or 4 percent figure) to arrive at the cost per job created. As an example, California's current New Jobs Credit (NJC) pays a credit of $\$ 3,000$ for a worker employed all year. If this particular credit creates jobs at a rate consistent with the windfall rates suggested above, then the adjusted figure yields a cost per job created of $\$ 37,500$ to $\$ 75,000$.

In a high unemployment economy with little aggregate job growth, it might be easier to pay hiring credits for new hiring, and hence reduce windfalls. At the same time, even during recessions the U.S. Bureau of Labor Statistics Job Openings and Labor Turnover Survey shows that many firms are growing while others are shrinking, so that some hiring would be occurring even at the trough of a recession, and even absent the incentives. Nonetheless, Bartik's (2001) very positive assessment of the NJTC - which recall was enacted to help in the recovery from a steep recession - claims a windfall wastage rate of only 67 percent. Applying that rate to the $\$ 3,000$ per worker under California's NJC 
would substantially lower the cost per job created, to about $\$ 9,100$. In the context of the NJTC, which paid a larger credit, Bartik calculates, based on an upper bound estimate of job creation as a result of the NJTC of 700,000 , that the cost per job created by the NJTC could have been as low as $\$ 13,500$ per job created (in 1998 dollars, or $\$ 17,765$ in 2009 dollars). Finally, in a recent proposal for a new hiring credit of 15 percent of additions to payroll subject to Social Security taxes, Bartik and Bishop (2009) estimate a cost per job created of about $\$ 28,000$ - a bit higher than some of these other estimates.

These estimated costs are gross costs of creating jobs through hiring credits. The net costs would be lower if the increased employment from hiring credits lowered other government costs and increased economic activity. The most obvious cost offsets from job creation are reductions in Unemployment Insurance payments and increases in tax receipts - likely to be only a fraction of the cost per job created, but probably a non-trivial fraction. Benefits may also come from multiplier effects. Even if financed from taxes, if hiring credits transfer income to those with a higher marginal propensity to consume out of income, a hiring credit can have short-run stimulative effects. ${ }^{24}$

The considerable uncertainty associated with these effects makes it impossible to pin down how much lower the net costs of hiring credits are compared to gross costs - although clearly they are lower. Nonetheless, Bartik and Bishop's (2009) calculations are noteworthy - at least as an illustration that the gross cost numbers could overstate many-fold the actual cost of hiring credits once these other offsets are taken into account. Combining their high presumed success rate in creating jobs, with the other estimates they make of extra GDP and hence government revenue produced by their hiring credit, the net cost per job created falls to a range of $\$ 4,700-\$ 6,300$. Even if these figures should be two to four times higher, they would still be well below some of the gross cost figures cited above, more so if a hiring credit when the unemployment rate is high is particularly effective at creating net job growth.

There may also be other benefits from the increased employment from hiring credits, including the longer-run beneficial effects of the employment induced by hiring credits on affected individuals'

\footnotetext{
${ }^{24}$ Bartik and Bishop (2009) estimate large effects via this channel that offset more than 75 percent of a hiring credit. They assume that each new job generates an addition to GDP equal to economy-wide average labor compensation $(\$ 62,000)$, although a lower compensation figure at the level of workers likely to benefit from hiring credits seems more reasonable.
} 
employment and earnings through the accumulation of labor market experience and skills. Evidence on whether hiring credits have effects that persist is sparse and ambiguous. Thus, there is probably little justification for assuming large gains from longer-term effects that extend past the time a worker is employed because of a hiring credit, although the effects are almost surely in this direction. ${ }^{25}$

Bringing all of the evidence together suggests a range of costs per job created using hiring credits focused on the unemployed of $\$ 9,100$ to $\$ 75,000$. The costs are more likely at the lower end of this range, and perhaps lower still if multiplier effects are significant.

\section{IV.D. Worker Subsidies}

Given the macroeconomic considerations discussed earlier, the potential for using worker subsidies to increase employment in response to the Great Recession and future severe recessions is probably quite limited, and the discussion here is correspondingly much briefer. Moreover, the EITC has broader goals than job creation, which reduce its effectiveness in achieving this more limited goal.

First, the original intent of the EITC in the United States was not to increase employment, but to boost incomes of low-income families. As described in Eissa and Hoynes (2011), when the EITC was first enacted in 1975, the goal was "to offset the Social Security payroll tax for low-income families with children" (p. 691). At the same time, it was enacted in a period of debate over alternative ways to help low-income families, including a Negative Income Tax, and according to Eissa and Hoynes it was chosen as a means of encouraging rather than discouraging work. Moreover, the main reason for the popularity and increasing generosity of the EITC in recent decades is probably this pro-work incentive that the EITC generates, which, along with welfare reform, has shifted the nation's income-support programs towards those that encourage work (see Blank, Card, and Robins, 2000). As the ensuing discussion explains, however, the broader goal of increasing incomes for a large number of low-income families with

\footnotetext{
${ }^{25}$ Bartik (2001, Ch. 5) suggests that long-run increases in employment and earnings based on temporary increases in labor demand are on the order of 10-20 percent (p. 148). However, these stronger conclusions come mainly from evidence other than that generated by hiring credits (such as the general evidence from labor economics of a positive effect of experience on the wage). Indeed the only hiring credit program from which estimates like this emerge is the Supported Work Program (studied by Couch, 1992). But this program involved far more extensive kinds of supports (such as mentoring, counseling, or training) than a typical hiring credit program would include - especially if the program focused on the unemployed rather than the disadvantaged. (In fact, Couch describes the Supported Work Program as an employment training program.)
} 
employed workers substantially interferes with the effectiveness of the EITC as a job creation policy.

Second, because of the EITC's broader income-support goals, its effects are considerably more complicated than the simple worker subsidy depicted in Figure 3, leading to more complicated predictions for employment and labor supply. The top panel of Table 2 presents the parameters of the federal EITC program, as of 2010. In 2010, the federal credit rate for a family with two qualifying children was 40 percent over the "phase-in" range, as earnings climbed from $\$ 0$ to $\$ 12,590$. For families with one child, the incentives were weaker, and there was a very small EITC available to those without children (since 1993). ${ }^{26}$ However, to cap benefits there was a maximum amount the credit could reach $-\$ 5,036$ in 2010 for a family with two qualifying children. The benefit then stayed fixed at this maximum over some range, called the "plateau" (from $\$ 12,590$ of income to $\$ 16,450$ ). Finally, the benefit was phased out at a rate of 21.06 percent, until it was eliminated at $\$ 40,363$. Many states have their own EITC's, which typically specify a percentage supplement to the federal EITC that is provided to families by the state, although state EITC's can differ along a number of dimensions. The states with their own EITC as of 2009 are listed in the bottom panel of Table 2.

The structure of the EITC generates complicated labor supply incentives. The EITC creates incentives for increased employment, with one possible exception, but also creates incentives for many of those already working to reduce their hours. For an individual initially not working, there is no ambiguity. The higher effective wage in the phase-in range generates a positive substitution effect, but there is no income effect because the person initially has no earnings. For those already working, in contrast, the predicted labor supply effects differ. For those employed but in the phase-in range the EITC raises the wage, with effects that could go in either direction depending on the strengths of the substitution and income effects. For those on the plateau there is only an income effect, which should reduce labor supply. And for those in the phase-out range there is still a negative income effect, plus a higher tax on earnings as benefits are phased out, creating even strong labor supply disincentive effects. These contradictory incentives are unavoidable given the need to phase out EITC benefits as income rises.

\footnotetext{
${ }^{26}$ The phrase "without children" means that there are not children that qualify the family for the higher EITC
} payment. 
Finally, in families with multiple workers an EITC could conceivably lead one spouse to leave the labor force in response to the higher income paid to the other spouse.

A third limitation of the EITC as a job creation strategy is that it is also prone to windfalls. Because of the structure of the EITC, benefits go to a large number of people who would be employed regardless of the policy - paralleling the problem of windfalls with hiring credits. Indeed these windfalls could be viewed as consonant with the central goal of the policy, which is to increase incomes among low-income families with employed people, rather than narrowly targeting those initially out of the workforce. As a result, there are likely to be even higher windfall costs for worker subsidies, which is reflected in the cost estimates discussed below.

Offsetting these limitations, the EITC might have some advantages in trying to increase jobs. First, the EITC does not generate stigma effects, since the employer typically has no idea whether an employee is eligible for or receiving the EITC. ${ }^{27}$ And second, the EITC is easily administered through the tax code. At the state level it is a simple matter to "piggyback" a state EITC onto the federal EITC calculation on the federal tax return. ${ }^{28}$ In contrast, state hiring credits are heterogeneous, and there appear to be no state hiring credit programs that function as simply add-ons to federal credits, which likely implies larger administrative and compliance costs.

The labor supply effects of the EITC have been studied extensively, most recently by Eissa and Hoynes (2011) and Meyer (2010). ${ }^{29}$ The empirical research has focused on single mothers, for whom there is overwhelming evidence of positive employment effects, with an elasticity of employment with respect to the net income provided by the EITC generally in the 0.7 to 1.2 range. Research on labor supply reductions among those already working usually finds negative, if modest, labor supply effects (Eissa and Hoynes, 1998; Hoffman and Seidman, 2003). The EITC appears to increase total hours of

\footnotetext{
${ }^{27}$ Most EITC recipients choose to take their payment as a lump sum at the end of the year rather than in each paycheck. (The latter was an option that ended after 2010.) This choice to take the lump sum may have been to avoid stigma effects.

${ }^{28}$ For example, see http://www.tax.state.ny.us/pdf/2009/fillin/inc/it215_2009_fill_in.pdf, http://www.iowa.gov/tax/forms/1040AShortBooklet09.pdf, line 19, and http://forms.marylandtaxes.com/current_forms/resident_booklet.pdf, p. 9 (viewed August 3, 2010).

${ }^{29}$ Most of the evidence comes from changes in the generosity of the federal EITC, although some also uses variation in state supplements to the federal EITC (Neumark and Wascher, 2011).
} 
work among women (Keane and Moffitt, 1998; Meyer and Rosenbaum, 2001), and Dickert, Houser, and Scholz (1995) estimate an overall net positive labor supply effect of the EITC, although it is not large relative to total labor supply. This calculation captures the essence of the EITC. It does increase labor supply, because of its strong effect on the employment margin. But it also raises incomes for many workers, diluting its cost effectiveness as a job creation policy - even putting aside the issue of its effectiveness during recovery from the Great Recession.

The wide diffusion of EITC benefits is reflected in calculations of the costs per job created by the EITC. As for hiring credits, the evidence on costs per job created via worker subsidies is only suggestive because we do not have readily-quantifiable measures of some of the costs and benefits. In addition, uncertainty about the negative labor supply effects, and the potential for many families to reap benefits without changing their behavior, lead to higher cost estimates and a considerably larger range of estimates.

Bartik (2001) estimates very high costs of job creation based on the major expansion of the EITC in the 1980 s and $1990 \mathrm{~s}$, with the estimated cost per job created ranging from $\$ 123,000$ to $\$ 3.3$ million dollars. However, these estimates are almost surely too high. First, Bartik uses the largest negative estimate from a study of the effect of the EITC on married women's labor supply (Eissa and Hoynes, 2004). Other estimates suggest no negative employment effect for married mothers - or at least not one that is statistically detectable (Eissa and Liebman, 1996). Second, Bartik's cost estimate uses estimated employment changes from expansions to the program, but to calculate costs per job created he divides the cost of the entire program, rather than the cost of the expansion, by the number of jobs created. The expansions studied by Eissa and Hoynes (2004) and Meyer and Rosenbaum (2001) cover the 1990-1996 period, when federal EITC expenditures increased by about $\$ 21$ billion (in 1999 dollars). Using this increase instead of the overall spending figure and assuming no disemployment effect for married women reduces the cost per job created to about $\$ 50,000$ to $\$ 117,000 .^{30}$

\footnotetext{
${ }^{30}$ There is additional uncertainty because the evidence on employment (and hours) effects has focused on two groups - single mothers and married women with children. These groups make up the lion's share of EITC beneficiaries and benefits -86.8 percent of benefits, and 66.2 percent of families that benefit, in 2007 (Meyer,
} 
The EITC has an important advantage relative to hiring credits, in that it is well-targeted to lowincome families (Scholz and Levine, 2001; Meyer, 2010). In addition, the evidence on the employment effects of worker subsidies is more compelling. The conclusions about the employment effects of worker subsidies are based on well-accepted, convincing research designs usually entailing difference-indifferences estimators or difference-in-difference-in-differences estimators that control for many confounding factors. In contrast, the evidence on hiring credits - and in particular, the NJTC - has limitations, most importantly the difficult of identifying the effect of the NJTC given that it was a national policy.

Nonetheless, viewed as a job creation strategy, the estimates of cost-effectiveness suggest that the cost of creating jobs with the EITC could be very high relative to the cost of creating jobs via hiring credits. And these costs are lower bounds during recovery from the Great Recession, when deficient aggregate demand renders worker subsidies particularly ineffective. In contrast, subject to the qualifications just mentioned regarding the strength of the evidence on countercyclical hiring credits, the latter are more likely to prove effective at speeding recovery from the Great Recession, and likely also future recessions.

\section{Using Hiring Credits to Boost Job Creation in Recovering from Severe Recessions}

The evidence discussed to this point indicates that hiring credits could be useful in spurring job creation, especially in response to severe recessions. This section and the next discuss a number of issues regarding the effectiveness of hiring credits in this context - including how to make them more effective. The conclusions, including those from the preceding section, are summarized in Table 3.

\section{V.A. Why Hiring Credits Might be Particularly Effective in Countering Severe Recessions}

There are a number of reasons why hiring credits may be particularly effective in countering the lingering effects of the Great Recession (and other severe recessions). In the short term, the overriding concern of policymakers is surely putting more people back to work after the Great Recession, and

2010). But absent information on whether EITC benefits for other groups (single men with children, and individuals and couples without children) increase employment, we cannot do a full accounting of the costs of creating jobs via the EITC. 
lowering the unemployment rate. As a result, hiring credits would focus on the unemployed, rather than narrower disadvantaged groups. Negative conclusions about the effects of hiring credits (e.g., DickertConlin and Holtz-Eakin, 2000) are based on evidence on the effects of hiring credits on employment of disadvantaged workers, for whom hiring credits are quite ineffective. In contrast, the evidence suggests that a hiring credit that is non-categorical or perhaps focused broadly on the unemployed has greater potential to create jobs.

Second, during the recovery from the Great Recession or other severe recessions such a hiring credit might be maximally effective, as stigma effects should be minimal. For example, with national unemployment currently hovering above 8 percent, eligibility for a hiring credit based on current unemployment may not send employers much of a bad signal; everyone understands that many people have become unemployed in the current downturn through no fault of their own.

Third, it is likely easiest to get the incentives for new hiring right when using hiring credits to counter severe recessions. In a period when employment growth is falling or largely stagnant, it should be a simpler matter to reward hiring that would not have occurred but for the credit, reducing windfalls for firms that would be hiring anyway. For the same reason, it may be easier to keep administrative costs low. For example, in the current environment, making eligibility based simply on whether a firm's employment is growing might pose acceptable windfall costs, and such a simple rule for establishing eligibility would impose smaller costs on firms, making the credit more effective. Perhaps tying a credit to firms whose employment is growing in industries that have had employment declines could reduce windfalls further while keeping administration simple. Similarly, a credit targeting the recently unemployed should be simple to administer, as it is easy to verify unemployment status.

Finally, although a non-categorical hiring credit would be unlikely to have good distributional effects in normal times, the distributional effects may be more favorable in the short-term. The Great Recession has had substantially more adverse effects on men than on women, as Figure 4 shows, owing to substantial employment declines in industries with a large share of males, in particular construction and manufacturing. Thus, although policies channeling resources towards men typically do not have the best 
distributional effects, a hiring credit that directs more of the benefits towards men would help those who have been hit hardest by the Great Recession (and who would likely be harder hit by future severe recessions as well, given the cyclical sensitivity of the industries in which men are concentrated). As a consequence, such a hiring credit would in many cases help families whose incomes are temporarily low because of an unemployed male.

\section{V.B. Hiring Credits vs. General Fiscal Stimulus as a Short-Term Policy Response}

The earlier discussion suggests a range of costs per job created using hiring credits focused on the unemployed of $\$ 9,100$ to $\$ 75,000$, with costs at the lower end more likely, and perhaps lower if we take account of multiplier effects. It is informative to compare these cost estimates to estimates of the costs the United States incurred for job creation via the fiscal stimulus - the American Recovery and Reinvestment Act (ARRA) - passed to counter the Great Recession. The Congressional Budget Office (CBO) estimated that through the second quarter of fiscal year 2010 total ARRA stimulus expenditures were $\$ 570$ billion and increased employment by 1.4 to 3.6 million jobs (CBO, 2010). These figures, which account for multiplier effects, imply costs per job created of $\$ 158,000$ to $\$ 407,000 .^{31}$

The estimated ranges of costs suggest that the costs of creating jobs via hiring credits could be much lower than the costs of job creation via the federal stimulus. For example, using the midpoints of the cost ranges of hiring credits and the ARRA implies that hiring credits would produce jobs at about 15 percent (1/6.7) of the cost of the ARRA. And even using the lowest estimate for the costs under the ARRA and the highest estimate for hiring credits, hiring credits are more than twice as effective per dollar spent.

There are, though, a number of issues that arise in thinking about whether this cost comparison is valid. First, given that ARRA spending was ramped up and then winded down, at one point should job creation be measured in a way that is comparable to the estimated costs per job created via hiring credits? The CBO estimates cited above pertain to a period when the ARRA was likely having a very large effect,

\footnotetext{
${ }^{31}$ The $\$ 570$ billion figure comes from the report's estimate that 70 percent of the total $\$ 814$ billion impact would have been spent by the end of fiscal year 2010, which ended in September 2010. And the employment figures come from the report's Table 1, which shows employment created through the third quarter of 2010 (that is, September, 2010) of 1.4 to 3.6 million.
} 
rather than later quarters when spending (and the effects) of ARRA had waned (CBO, 2011).

Reinforcing this point, a 2009 report from the White House also emphasized that 2010 was the peak year for projected job creation under the ARRA, precisely because of when the stimulus spending was slated to occur (Council of Economic Advisors, 2009). Given that much of the information used to estimate costs per job created by hiring credits comes from either the NJTC or studies of these costs in the midst of the Great Recession or early in the recovery, the comparison periods are appropriate.

A second question is whether the jobs created under the different policies are comparable, given that jobs are not permanent. The $\mathrm{CBO}$ estimates the amount by which employment was contemporaneously higher because of ARRA, without regard to how long the jobs last. The estimates for hiring credits based on the NJTC pertain to similar short-term, countercyclical efforts, and likely also similar workers when those targeted by a broad-based hiring credit would be those who are cyclically unemployed. Thus, again, to a first-order approximation the ARRA vs. hiring credit cost figures compare apples to apples

On the other hand, the comparison may be less fair because one could argue that the goal of ARRA was not simply job creation, but also the building up of public infrastructure. Investment in infrastructure is necessary, and it may be most efficient to do this when the economy is operating below full employment (The Department of the Treasury with the Council of Economic Advisers, 2010), offsetting the likelihood that public spending on infrastructure is not the most efficient way to create jobs in the short term. Nonetheless, the ARRA was clearly touted as a means to create and save jobs (Council of Economic Advisors, 2009), so a comparison on the grounds of job-creation costs is at least to some extent warranted.

Moreover, in thinking about additional policy efforts to help with recovery from the Great Recession, infrastructure investment would likely loom less large, and job creation be an even more clear priority. Viewed through this lens, the estimates suggest that there may be scope for a significant federal job creation hiring credit that could have effects on the scale of ARRA, at much lower cost. For example, using the midpoints of the cost estimates of the alternative job creation policies (which imply that hiring 
credits are 6.7 times more effective), a $\$ 50$ billion hiring credit program would create almost 1.2 million jobs - nearly the lower range of the CBO estimate of the effect of the ARRA as of late 2010 - with expenditures less than one-tenth of what ARRA spent. Thus, if additional job creation policies are to be adopted, the federal government can get a great deal more bang for its buck by focusing on hiring credits.

Turning this around, because a hiring credit policy might deliver a great deal of bang without spending a prohibitive amount of bucks, it may be far more politically feasible than additional general stimulus. And it might be easier to obtain political agreement on an aggressive hiring credit than on additional general stimulus spending, as a hiring credit lowers costs for businesses and relies on the private sector to generate job growth.

\section{V.C. Making Hiring Credits More Effective}

The research literature points to a number of ways to make a non-categorical countercyclical hiring credit more effective. First, hiring credits are likely to be more effective if they are temporary. Reducing the cost of hiring for a short, predefined period is more likely to shift hiring into that period exactly the goal of countercyclical policy.

Second, although hiring credits have sometimes focused on smaller employers, this may not be optimal. The basis for designing hiring credits this way is, presumably, because smaller firms contribute (moderately) disproportionately to net job growth (Neumark, Wall, and Zhang, 2011). But this fact does not imply that small firms are more responsive to hiring credits than are large firms, and earlier evidence suggests that it is primarily large firms that take advantage of hiring credits (Perloff and Wachter, 1979), perhaps because fixed administrative costs deter small firms. In addition, recent research shows that the disproportionate contribution of small firms to job growth comes solely from newer firms (Haltiwanger, Jarmin, and Miranda, 2009), so targeting small firms per se may not be effective.

Finally, an important issue is whether hiring credits should subsidize only new employment, or increases in hours for existing employees as well (as, for example, in the hiring credit proposed by Bartik and Bishop, 2009). A large research literature on labor supply concludes that labor supply on the intensive margin (adjustments of hours conditional on working) is quite inelastic, while labor supply on 
the extensive margin (the employment decision) is more elastic (Heckman, 1993). The elasticity of the labor supply curve plays a key role in determining the effects of a hiring credit. To take an extreme case, suppose supply is completely inelastic (Figure 5, Panel A). In this case when the labor demand curve shifts there is no employment increase, and only a wage increase; workers' wages increase by the full amount of the credit, and firm's labor costs are unchanged. Thus, when labor supply is relatively inelastic, hiring credits result mainly in higher wages for existing workers, and fail to create many jobs. In contrast, when labor supply is very responsive to wages, a hiring credit pushes out the labor demand curve against a relatively flat labor supply curve, generating a large employment increase but not much wage increase (the extreme case is shown in Figure 5, Panel B).

Thus, a credit that subsidizes the extensive margin will lead to larger effects on total hours of work. So even if we are agnostic about the merits of creating more "full-time equivalent" employment through employment of more people or increased hours, a hiring credit that creates incentives for new employment is likely to be more effective. ${ }^{32}$ One potential qualification to this conclusion is that during the recovery from the Great Recession, when part-time work is more prevalent, ${ }^{33}$ there could be a bit more labor supply responsiveness on the intensive margin than is suggested by the broader labor supply literature.

Note that the two federal hiring credits enacted or proposed to counter the Great Recession fail to meet some of these criteria for the most effective hiring credits, although both are - to their credit largely non-categorical. In particular, the HIRE Act did not explicitly target job creation by, for example, rewarding hiring only in growing businesses. And the recently-proposed AJA would subsidize hiring in two ways: exempting employers from the payroll tax for increases in payroll, whether via employment, hours, or wages; and providing a $\$ 4,000$ credit for hiring those unemployed more than six months. The payroll tax exemption would only create incentives for added jobs if we assume that payroll expansions primarily occur as new hires rather than increased hours of work (or wages). However, as currently

\footnotetext{
${ }^{32}$ On the other hand, a credit that targets employment per se could encourage part-time hiring. If that is viewed as undesirable, the value of the credit could be tied to hours worked by new hires.

${ }^{33}$ See http://data.bls.gov/pdq/querytool.jsp?survey=ln (viewed June 26, 2012).
} 
structured, the AJA's payroll tax holiday also applies to businesses that increase hours without necessarily increasing the number of employees. As just noted, because labor supply on the employment margin is much more responsive to wages than is labor supply on the hours margin, limiting the AJA's payroll tax holiday to increases in employment would enhance the likelihood that it would create a substantial number of new jobs.

Finally, the current, broader temporary cut in the payroll tax rate on workers from 6.2 percent to 4.2 percent should probably be viewed as general tax relief intended to provide fiscal stimulus, rather than a policy to promote hiring. ${ }^{34}$ If it is viewed as a policy to promote hiring, it is a particularly poorlydesigned policy, as the credit is paid for all employees, without trying to target new hiring.

\section{Monitoring, Implementation, and Thinking Ahead}

\section{VI.A. Keeping Hiring Credits Effective}

It is important to design hiring credits to minimize windfalls to employers and create strong incentives for job creation. But research on the political economy of hiring credits also points to the importance of ensuring that the longer-term implementation of the credit is not distorted to increase windfalls. Lorenz's (1995) discussion of the TJTC is instructive. The policy was intended to minimize windfalls by mandating ongoing program evaluation, with reporting to Congress on the credit's effectiveness in increasing employment among targeted groups. Lorenz argues, however, that via the oversight process interest groups distorted the credit into "a windfall for businesses that hire large numbers of low wage workers" (p. 270). Thus, even when a hiring credit was designed in recognition of the problem of windfalls, and mechanisms were built into the policy to minimize these windfalls, policymakers had difficulty resisting efforts that increased the value of the hiring credit to businesses while reducing its effectiveness and increasing its costs.

Some steps that have been adopted or proposed with respect to other hiring credits may help. For example, Bartik (2001) suggests that to avoid claiming credits for retroactive claiming, under the WOTC and the WtW tax credits employers and applicants are required to fill out and sign a form on or before the

\footnotetext{
${ }^{34}$ This is the case despite the name of the legislation that most recently extended the payroll tax cut - the Middle Class Tax Relief and Job Creation Act of 2012.
} 
data of hire including information indicating that the hire is probably eligible. Similarly, recent proposals regarding California's enterprise zone program (a geographically-targeted hiring credit) would have eliminated retroactive claiming of credits (Brown, 2011).

Of course these are steps that are designed, ex ante, to reduce the distortions of hiring credits that can increase their cost and reduce their effectiveness. Given the strong incentives for businesses to expand the scope of hiring credits that reduce their tax bills, and notwithstanding the best efforts at policy design, continued evaluation of countercyclical hiring credits is necessary to verify whether credits have beneficial effects at reasonable cost.

\section{VI.B. A Better Policy Response to Future Severe Recessions}

Experience from policy responses to the Great Recession indicates that enacting new hiring credits in the midst of or following a severe recession can prove difficult because of budgetary constraints, resulting in too little, too late - or in nothing at all. Indeed it is likely that the period when aggressive hiring credits could have had the greatest impact in helping with recovery from the Great Recession is already behind us. As indicated in Figure 1, we are well past the trough of the recession, yet policymakers are still debating hiring credits (e.g., in the AJA proposed by President Obama in late 2011). This is not to say that hiring credits would not still have considerable impact; indeed, it is possible that the marginal incentives created by hiring credits are stronger further from the trough. Nonetheless, enacting hiring credits much closer to the beginning of a recession runs little risk, if the credit is well-designed, as the cost of the credit is incurred when the hiring occurs. As salient examples of the failure to enact hiring credits in a timely manner, the HIRE Act was only enacted in 2010, and the AJA was only proposed in 2011, while the recession began in late 2007 and the trough was reached in mid-2009. ${ }^{35}$

The experience of the Great Recession suggests that the federal and state governments would likely be better prepared to counter future recessions if they enacted hiring credits that remain on the books permanently, but which more aggressively reward hiring unemployed workers during economic

\footnotetext{
${ }^{35}$ See http://www.nber.org/cycles.html (viewed May 7, 2012).
} 
downturns and "turn off" during better economic times. To provide certainty to employers, and to avoid political decision-making interfering with the credits taking effect, these might be triggered by preestablished criteria such as a particular level of the unemployment rate or a specific number of months at or above that level. Like with Unemployment Insurance benefits, a federal credit could use criteria that are determined at the state level, to target the credit towards states where the impact would be greater.

A countercyclical hiring credit, like other "automatic stabilizers," could help cushion the blow from future recessions. It might be particularly valuable because it creates direct incentives for the creation of jobs, in contrast to the less direct effects of other automatic stabilizers - like the income support provided by Unemployment Insurance or the lower tax payments generated when incomes decline in a progressive tax system. And finally, automatic rules for hiring credits taking effect, and also ending, could help avoid the distortion of these credits, over time, into general tax relief that does less to incentivize job creation. $^{36}$

At the same time, it is important to re-emphasize that the arguments in favor of broadly-based hiring credits are based partly on theoretical conjecture, and partly on evidence - from the NJTC - that is quite old. The simple fact is that we do not have much experience or depth of knowledge - from either the research or the policy side - with the design and implementation of effective countercyclical hiring credit programs, given that we have had only one large-scale program like this (the NJTC), it was decades ago, and the evidence is less conclusive than what we now expect from the most rigorous empirical analyses of policy effects.

We therefore need more evidence on the effects of these types of hiring credits. Some of this may be available from past experience in the many states that implemented broadly-based hiring credits. But even more important, newly-established hiring credits should be coupled with ongoing efforts to evaluate their effectiveness - fine-tuning them in ways that are found to increase effectiveness, and being willing to scrap them if they prove ineffective. Lest we be too cautious, however, it should be

\footnotetext{
${ }^{36}$ This proposal has parallels to other automatic stabilizers - in particular temporary income transfers and temporary consumption tax cuts - proposed by Seidman (2003). Indeed he also proposes using such "pre-enacted" automatic stabilizers to overcome potential political problems - ensuring that these stimuli are implemented quickly when the economy slows down, and avoiding growing debt by ensuring that they are eliminated when the economy recovers.
} 
recognized that U.S. policymakers have tried a wide variety of policies to counter the Great Recession many at much greater cost than even an ambitious hiring credit policy - with a less solid basis of evidence for establishing that these policies would work than exists with regard to broadly-based hiring credits. This experience illustrates that policymakers may not have the luxury of holding policy efforts hostage to exacting standards of evidence when there is a strong need for policy intervention - a perspective that should be kept in mind in contemplating the enactment of hiring credits. 
Affiliations: David Neumark is Professor of Economics and Director of the Center for Economics \& Public Policy at the University of California, Irvine. He is also a research associate of the NBER and a research fellow at IZA.

Acknowledgments: I am grateful to Marisol Cuellar Mejia for outstanding research assistance and to Timothy Bartik, Doug Besharov, Vera Brusentsev, Karen Chapple, David Crane, John Laird, Marisol Cuellar Mejia, Carolyn Danielson, Hans Johnson, Jed Kolko, Wayne Vroman, and anonymous referees for helpful comments and discussions. This research was initiated when the author was a Bren Fellow at the Public Policy Institute of California, supported in part by the Donald Bren Foundation. But the views are solely those of the author. 


\section{References}

Bartik, T. J. (2001). Jobs for the poor: Can labor demand policies help? New York: Russell Sage Foundation.

Bartik, T. J., \& Bishop, J. H. (2009). The Job Creation Tax Credit: Dismal projections for employment call for a quick, efficient, and effective response. Economic Policy Institute Briefing Paper No. 248, Washington, DC, October 20.

Bartik, T. J., \& Erickcek, G. (2010). The employment and fiscal effects of Michigan's MEGA tax credit program. Upjohn Institute Working Paper No. 10-164.

Bishop, J. (2008). The 1977-78 New Jobs Tax Credit was a big success. Can a tax credit for employment growth in 2009 and 2010 restore animal spirits and help jump start the economy. Cornell University. Retrieved December 21, 2010, from http://digitalcommons.ilr.cornell.edu/cgi/viewcontent.cgi? article $=1185 \&$ context $=$ articles.

Bishop, J. H. (1981). Employment in construction and distribution industries: The impact of the New Jobs Tax Credit. In S. Rosen (Ed.), Studies in labor markets (pp. 209-46). Chicago: University of Chicago Press.

Bishop, J., \& Haveman, R. (1978). Targeted employment subsidies: Issues of structure and design. University of Wisconsin - Madison, Institute for Research and Poverty, Special Report Series - SR 24. Retrieved May 8, 2012, from http://www.eric.ed.gov/PDFS/ED190723.pdf.

Blank, R. M., Card, D. E., \& Robins, P. K. (2000). Financial incentives for increasing work and income among low-income families. In D. E. Card \& R. M. Blank (Eds.) Finding jobs: Work and welfare reform (pp. 373-419). New York: Russell Sage Foundation.

Bloom, H. S., Orr, L. L., Cave, G., Bell, S. H., Doolittle, F., \& Lin, W. (1994). The National JTPA Study: Overview: Impacts, benefits, and costs of Title II-A. Bethesda, MD: Abt Associates, January.

Borjas, G. (2010). Labor economics, fifth edition. New York: McGraw-Hill.

Brown, E. G. Jr., Governor. (2011). 2011-2012 Governor's budget May revision. Retrieved June 6, 2011, from http://www.ebudget.ca.gov/pdf/Revised/BudgetSummary/FullBudgetSummary.pdf.

Burtless, G. (1985). Are targeted wage subsidies harmful? Evidence from a wage voucher experiment. Industrial and Labor Relations Review, 39, 105-114.

Cahuc, P., \& Zylberberg, A. (2001). Labor economics. Cambridge, MA: MIT Press.

Chirinko, R. S., \& Wilson, D. J. (2010). Job creation tax credits and job growth: Whether, when, and where? Federal Reserve Bank of San Francisco Working Paper 2010-25.

Congressional Budget Office. (2010). Estimated impact of the American Recovery and Reinvestment Act on employment and economic output from April 2010 through June 2010. Washington, DC:

Congressional Budget Office.

Congressional Budget Office. (2011). Estimated impact of the American Recovery and Reinvestment Act on employment and economic output from January 2011 through March 2011. Washington, DC:

Congressional Budget Office.

Couch, K. A. (1992). New evidence on the long-term effects of employment training programs. Journal of Labor Economics, 10, 380-388.

Council of Economic Advisers. (2009). Estimates of job creation from the American Recovery and Reinvestment Act of 2009. Washington, D.C.: Executive Office of the President of the United States. Retrieved June 26, 2012, from http://www.whitehouse.gov/sites/default/files/microsites/Estimate-of-JobCreation.pdf.

Dickert, S., Houser, S., \& Scholz, J. K. (1995). The Earned Income Tax Credit and transfer programs: A 
study of labor market and program participation. Tax Policy and the Economy, 9, 1-50.

Dickert-Conlin, S., \& Holtz-Eakin, D. (2000). Employee-based versus employer-based subsidies to lowwage workers: A public finance perspective. In D. E. Card \& R. M. Blank (Eds.) Finding jobs: Work and welfare reform (pp. 373-419). New York: Russell Sage Foundation.

Edelman, P., Greenberg, M., Holt, S., \& Holzer, H. (2009). Expanding the EITC to help more low-wage workers. Washington, DC: Georgetown Center on Poverty, Inequality and Public Policy. Retrieved October 5, 2011, from http://www.urban.org/uploadedpdf/1001341_eitc.pdf.

Ehrenberg, R. G., \& Smith, R. S. (2009). Modern labor economics, tenth edition. Boston, MA: Pearson Education, Inc.

Eissa, N., \& Hoynes, H. (2011). Redistribution and tax expenditures: The Earned Income Tax Credit. National Tax Journal, 64, 689-730.

Eissa, N., Hoynes, H. W. (2004). Taxes and the labor market participation of married couples: The Earned Income Tax Credit. Journal of Public Economics, 88, 1931-1958.

Eissa, N., \& Liebman, J. B. (1996). Labor supply response to the Earned Income Tax Credit. Quarterly Journal of Economics, 111, 605-637.

Ellwood, D. T., \& Welty, E. D. (2000). Public service employment and mandatory work: A policy whose time has come and gone and come again?" In D. E. Card \& R. M. Blank (Eds.) Finding jobs: Work and welfare reform (pp. 299-372). New York: Russell Sage Foundation, pp. 299-372.

Haltiwanger, J., Jarmin, R. S., \& Miranda, J. (2009). Who creates jobs? Small vs. large vs. young. Unpublished paper, University of Maryland.

Hamersma, S. (2011). Why don't eligible firms claim hiring subsidies? The role of job duration. Economic Inquiry, 49, 916-934.

Hamersma, S. (2008). The effects of an employer subsidy on employment outcomes: A study of the Work Opportunity and Welfare-to-Work Tax Credits. Journal of Policy Analysis and Management, 27, 498-520.

Hamersma, S. (2005). The Work Opportunity and Welfare-to-Work Tax Credits. Urban-Brookings Tax Policy Center Brief, No. 15, October, Washington, DC.

Hamermesh, D. (1993). Labor demand. Princeton, NJ: Princeton University Press.

Heckman, J. T. (1993). What has been learned about labor supply in the past twenty years? American Economic Review Papers and Proceedings, 83, 116-121.

Hoffman, S. D., \& Seidman, L. S. (2003). Helping working families: The Earned Income Tax Credit. Kalamazoo, MI: W.E. Upjohn Institute for Employment Research.

Katz, L. F. (1998). Wage subsidies for the disadvantaged. In R. B. Freeman \& P. Gottschalk (Eds.) Generating jobs: How to increase demand for less-skilled workers (pp. 21-53). New York, NY: Russell Sage Foundation.

Keane, M., \& Moffitt, R. (1998). A structural model of multiple welfare program participation and labor supply. International Economic Review, 39, 553-589.

Lorenz, E. C. (1995). TJTC and the promise and reality of redistributive vouchering and tax credit policy. Journal of Policy Analysis and Management, 14, 270-290.

Lower-Basch, E. (2011). Rethinking work opportunity: From tax credits to subsidized job placements. CLASP, Washington, DC. Retrieved May 9, 2012, from http://www.clasp.org/admin/site/publications/files/Big-Ideas-for-Job-Creation-Rethinking-WorkOpportunity.pdf).

Lucas, R. E., Jr., \& Rapping, L. A. (1969). Real wages, employment, and inflation. Journal of Political Economy, 77, 721-754. 
Meyer, B. D. (2010). The effects of the Earned Income Tax Credit and recent reforms. In J. R. Brown (Ed.) Tax policy and the economy, volume 24 (pp. 153-80). Chicago: University of Chicago Press.

Meyer, B. D., \& D. T. Rosenbaum. (2001). Welfare, the Earned Income Tax Credit, and the labor supply of single mothers. Quarterly Journal of Economics, 116, 1063-1114.

Mulligan, C. B. Forthcoming. The redistribution recession: How labor market distortions contracted the economy. New York: Oxford University Press.

National Community Tax Coalition. (2010). Refundable tax credits: A permanent solution for working families. Chicago, IL: National Community Tax Coalition. Retrieved October 5, 2011, from http://taxcoalition.org/policy-resources/tax-policy/policy-brief-refundable-tax-credits-a-permanent-solution-forworking-families.

Neumark, D., \& Kolko, J. (2010). Do enterprise zones create jobs? Evidence from California's enterprise zone program. Journal of Urban Economics, 68, 1-19.

Neumark, D., \&, Wascher, W. L. (2011). Does a higher minimum wage enhance the effectiveness of the Earned Income Tax Credit? Industrial and Labor Relations Review, 64, 712-746.

Neumark, D., Wall, B., \& Zhang, J. (2011). Do small businesses create more jobs? New evidence for the United States from the National Establishment Time Series. Review of Economics and Statistics, 93, 1629.

Perloff, J. M., \& Wachter, M. L. 1979. The New Jobs Tax Credit: An evaluation of the 1977-78 wage subsidy program. American Economic Review Papers and Proceedings, 69, 173-179.

Scholz, J. K., \& Levine, K. (2001). The evolution of income support policy in recent decades. In S. Danziger \& R. Haveman (Eds.) Understanding poverty (pp. 193-228). Cambridge and New York: Harvard University Press and Russell Sage Foundation.

Seidman, L. S. (2003). Automatic fiscal policies to combat recessions. Armonk, NY: M.E. Sharpe, Inc.

The Department of the Treasury with the Council of Economic Advisers. (2010). An economic analysis of infrastructure investment." Retrieved June 6, 2011, from http://www.treasury.gov/resourcecenter/economic-policy/Documents/infrastructure_investment_report.pdf. 
Figure 1: Changes in Employment and Unemployment in the United States

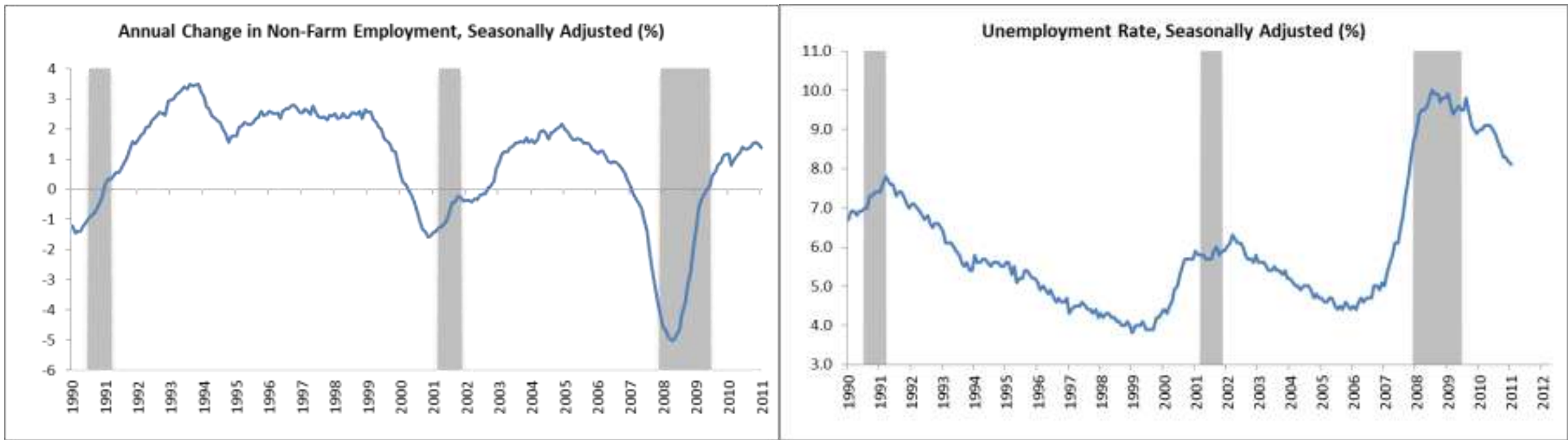

Source: The left-hand panel is based on the Current Employment Statistics payroll survey, and the right-hand panel on the Bureau of Labor Statistics Current Population Survey. 
Figure 2: The Effects of a Hiring Credit

A. Effects of on wages and employment

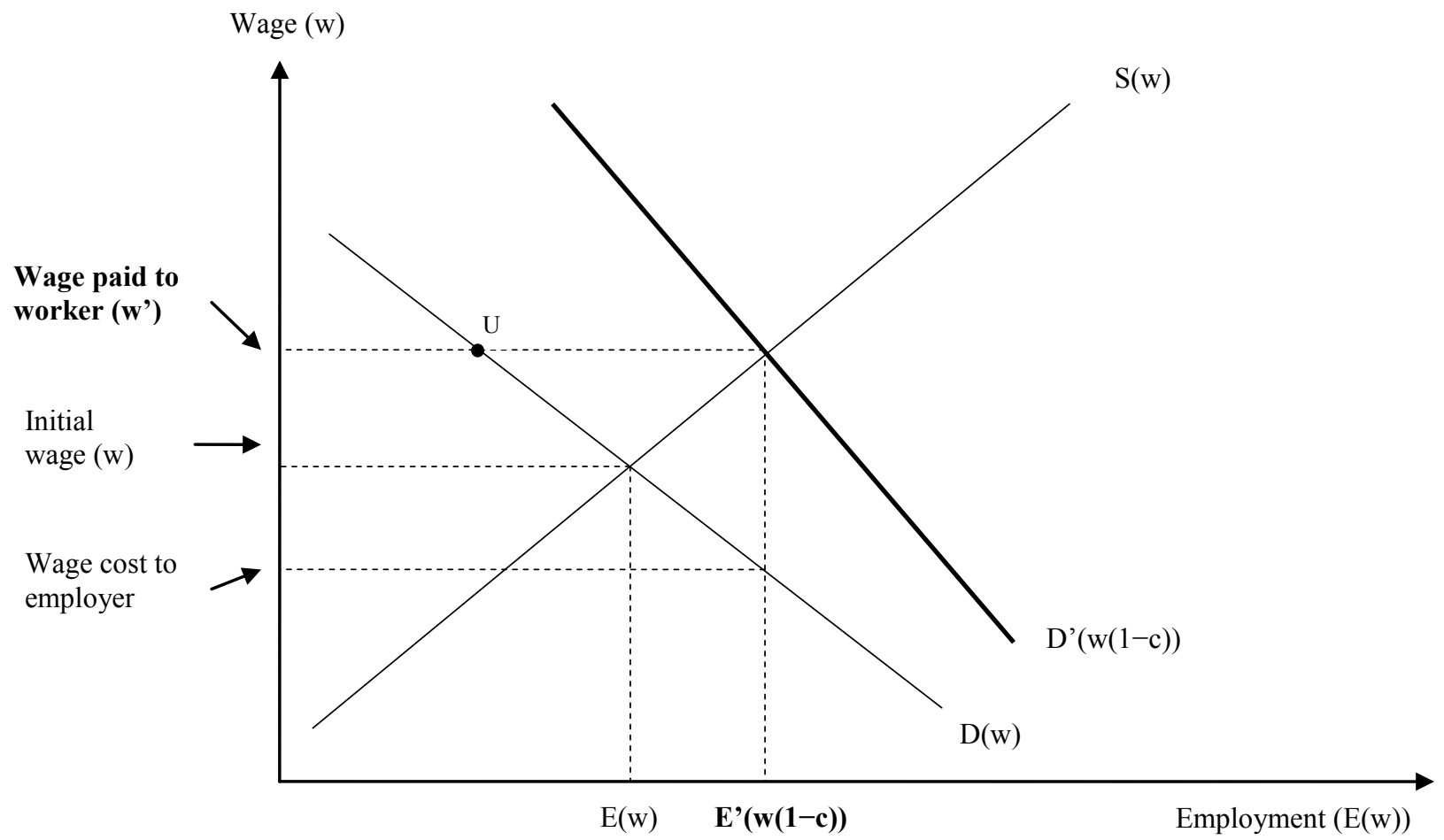

B. Windfall (A) and subsidy payments for increased employment (B)

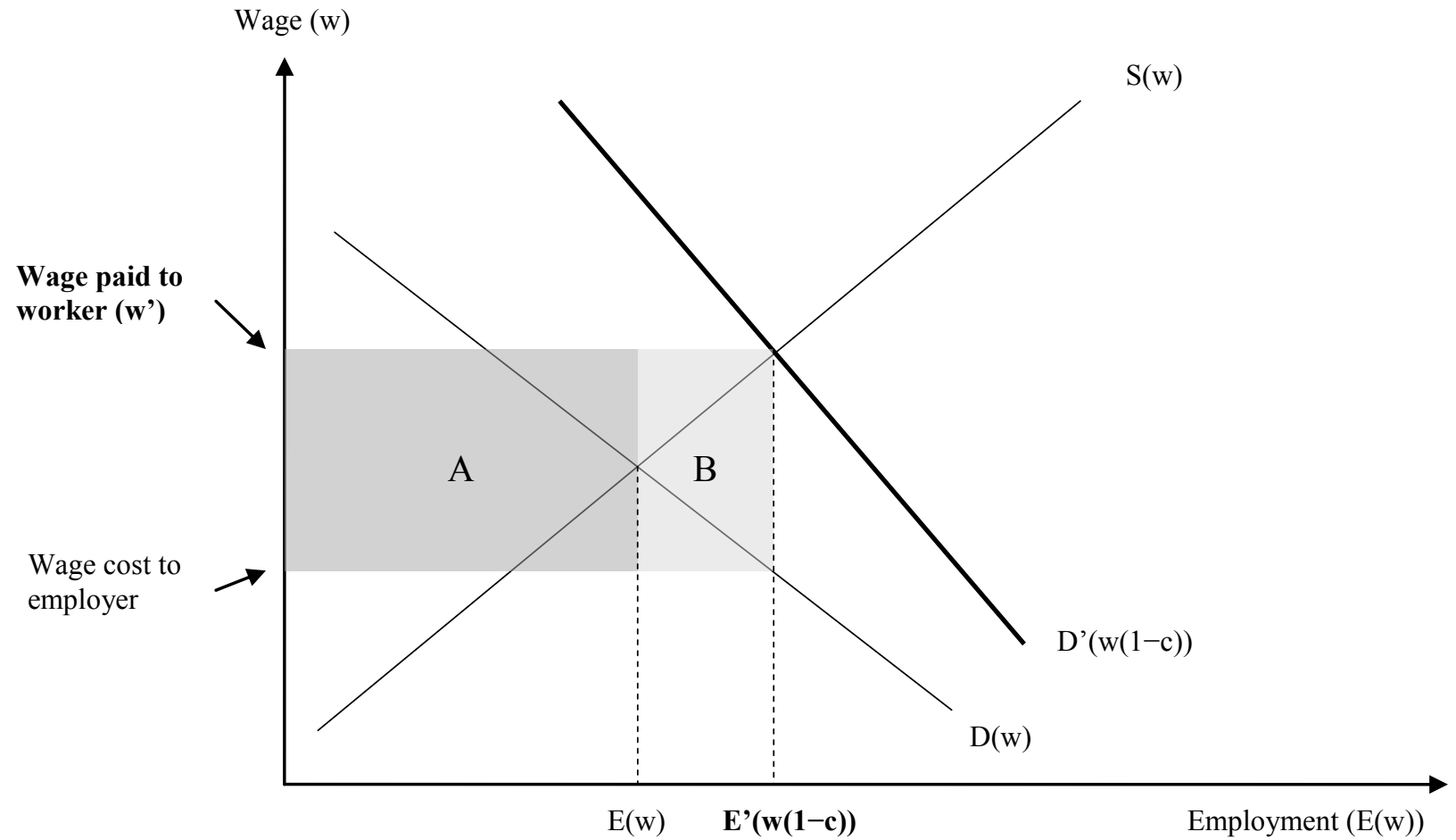


Figure 3: The Effects of a Worker Subsidy (e)

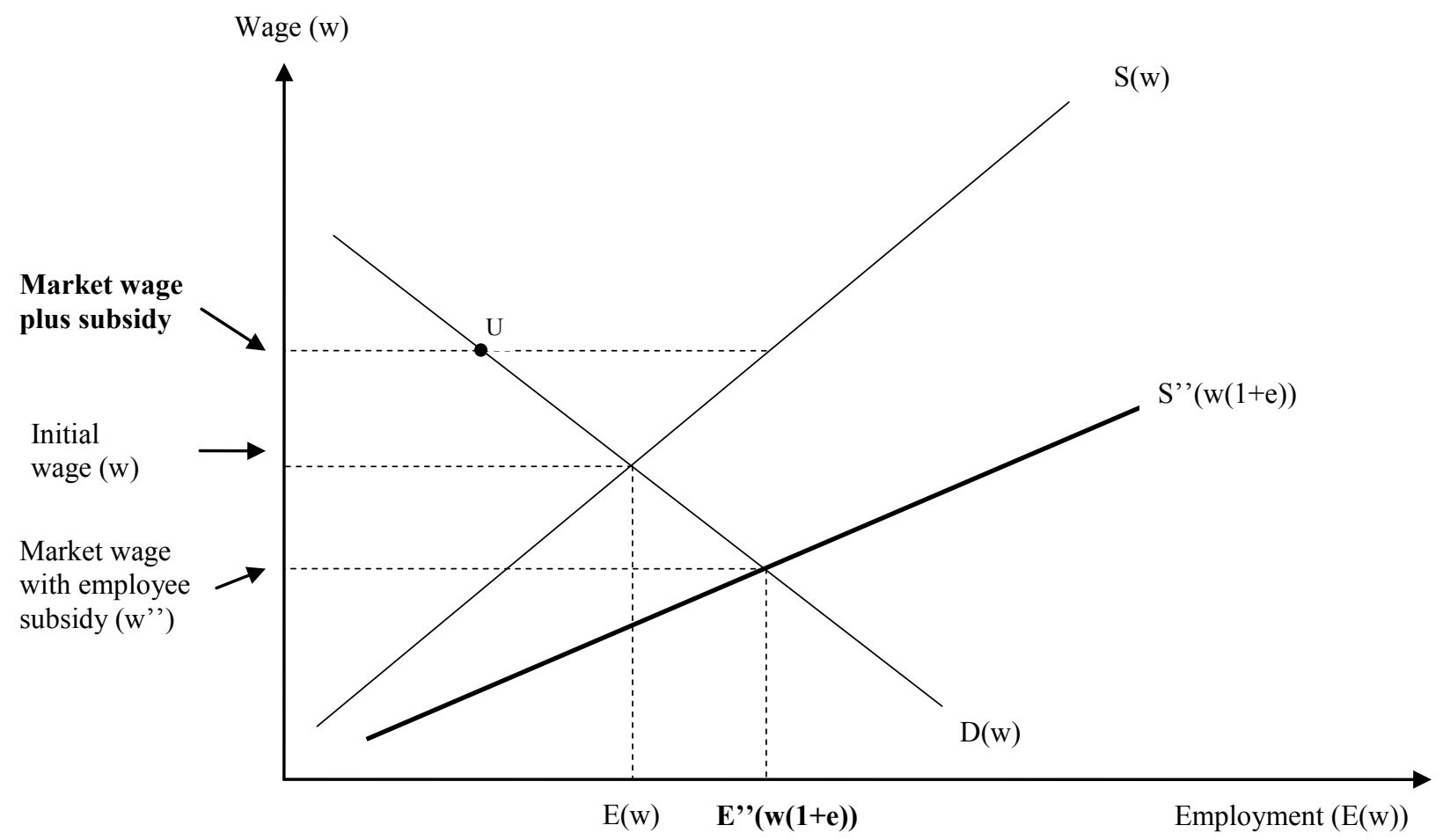


Figure 4: Employment Change and Unemployment of Men and Women

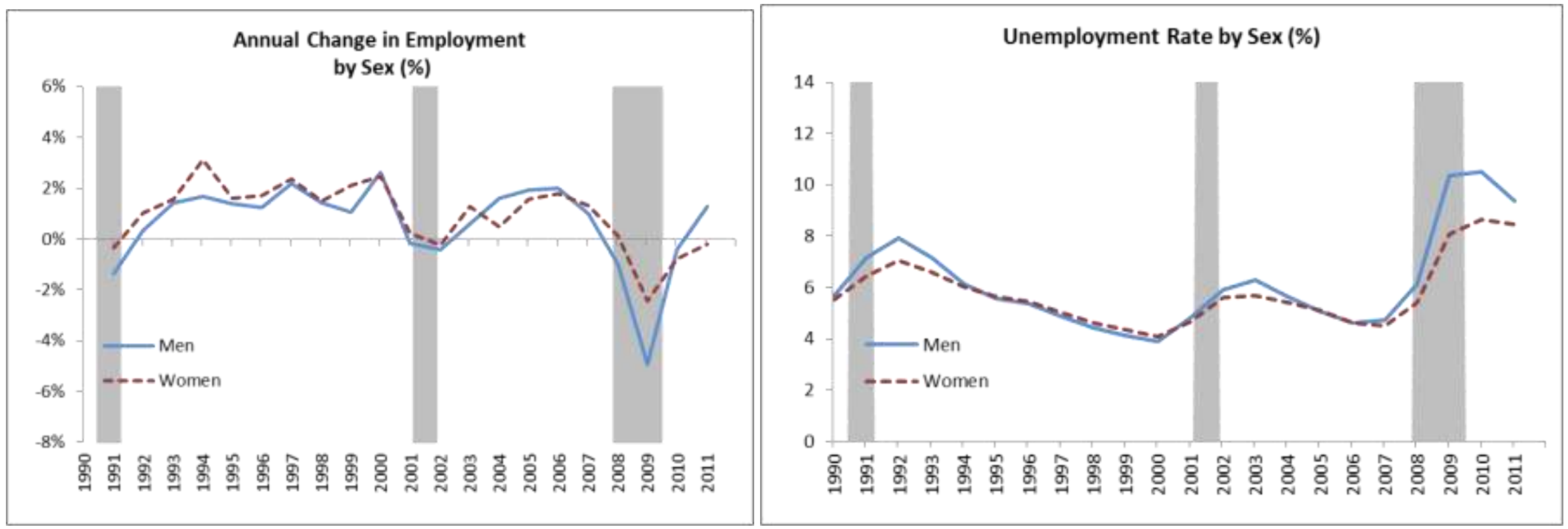

Source: Bureau of Labor Statistics Current Population Survey, Annual Averages. 
Figure 5: The Effects of Hiring Credits in Cases of Completely Inelastic Labor Supply or Infinitely Elastic Labor Supply

A. Hiring credit (c) with completely inelastic labor supply

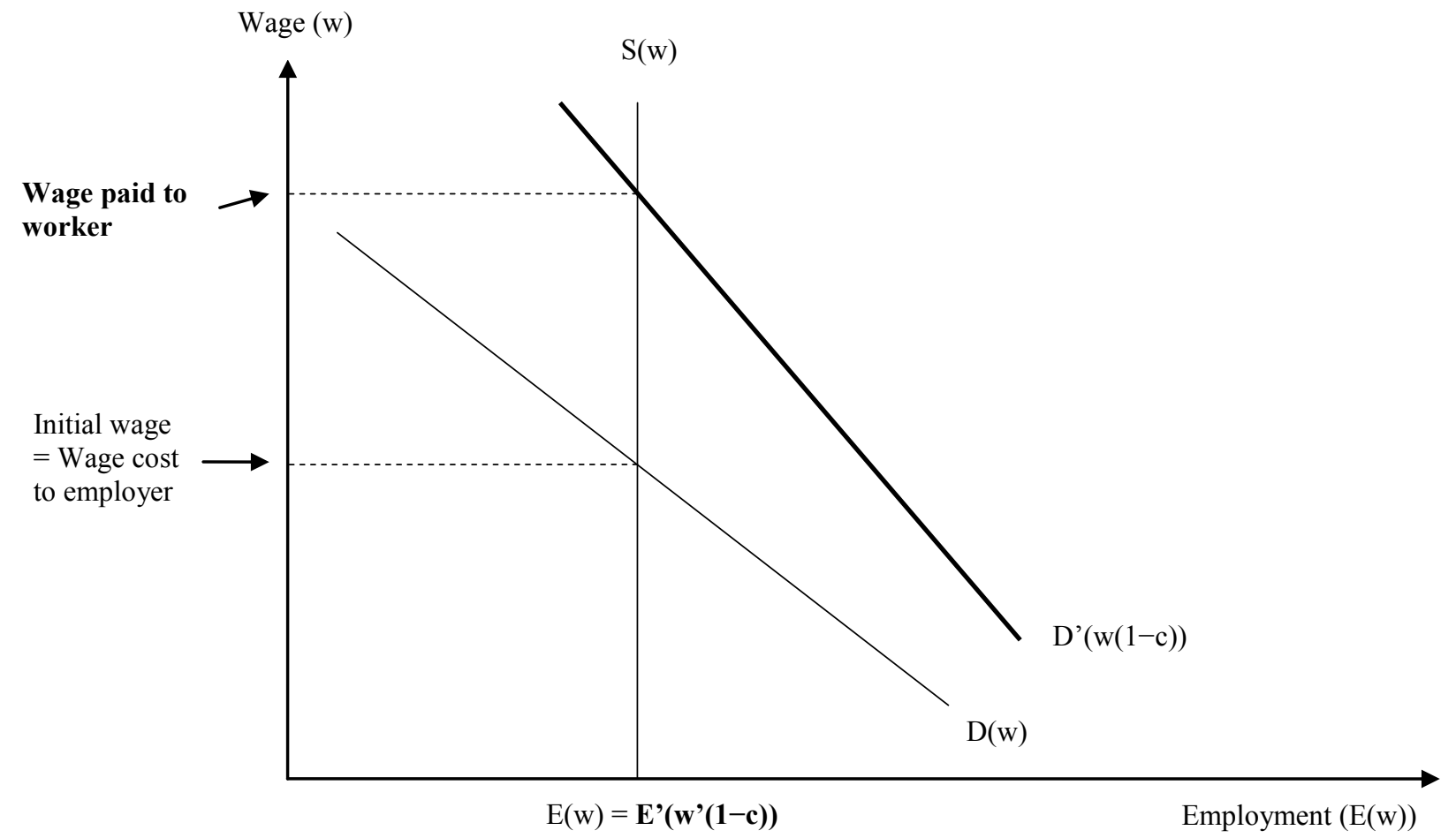

B. Hiring credit (c) with completely elastic labor supply

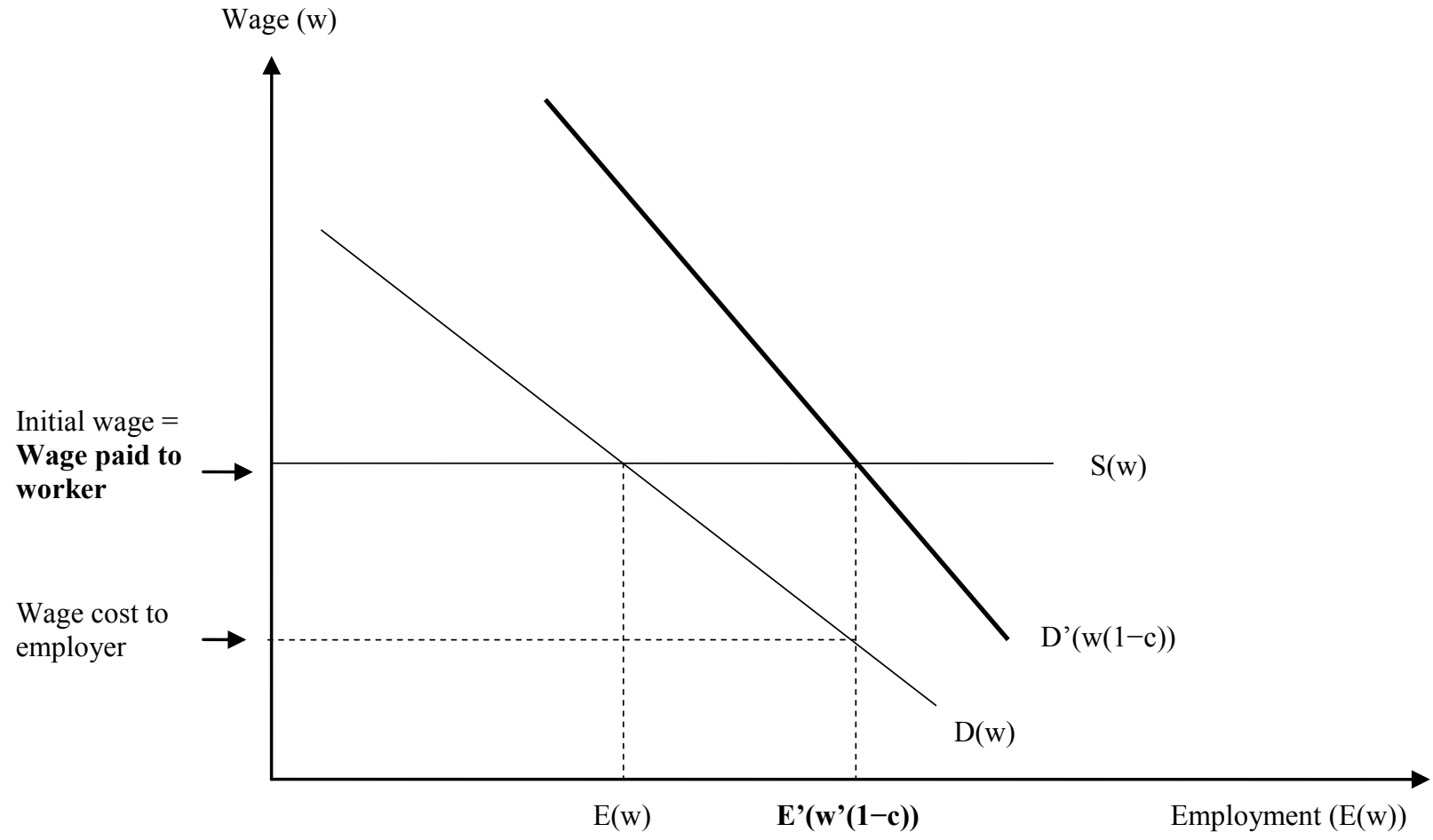


Table 1: Hiring Credits, 2010

\section{A. Federal}

\begin{tabular}{|c|l|}
\hline HIRE Act & $\begin{array}{l}\text { Exemption from employer share of Social Security taxes (6.2 percent) for March-December } \\
\text { 2010; \$1,000 tax credit per worker; for workers unemployed or not employed (more than } 40 \\
\text { hours total) in } 60 \text { days prior to hire; for hires into new positions or existing positions if } \\
\text { previous worker left voluntarily or for cause }\end{array}$ \\
\hline WOTC & $\begin{array}{l}\text { Varying maximum credit amounts for long-term and other TANF recipients, Veterans, SNAP } \\
\text { recipients, residents of designated communities, summer youth, disabled, ex-felons, SSI } \\
\text { recipients, Katrina "employees," disconnected youths hired for two-year period; credit is } \\
\text { percentage of qualified wages, which are capped (percentage and cap vary by group) }\end{array}$ \\
\hline
\end{tabular}

\begin{tabular}{|c|c|c|}
\hline \multicolumn{3}{|r|}{ B. States (examples) } \\
\hline Connecticut & $\begin{array}{l}\text { New Jobs } \\
\text { Creation Tax } \\
\text { Credit }\end{array}$ & $\begin{array}{l}\text { Discretionary tax credit up to } 60 \text { percent of the income tax for taxpayers that } \\
\text { create and maintain at least } 10 \text { full-time new jobs }\end{array}$ \\
\hline Delaware & $\begin{array}{l}\text { Blue Collar } \\
\text { Job Act }\end{array}$ & $\begin{array}{l}\text { Credits up to } 50 \text { percent of firm's tax liability for eligible businesses that are } \\
\text { engaged in a qualified activity, hire five or more qualified employees; and } \\
\text { invest at least } \$ 200,000 \text { ( } \$ 40,000 \text { per qualified employee) in a qualified } \\
\text { facility; also } \$ 400 \text { corporate income tax credit per employee and per } \$ 100,000 \\
\text { investment }\end{array}$ \\
\hline Florida & $\begin{array}{l}\text { Jobs for the } \\
\text { Unemployed } \\
\text { Tax Credit } \\
\text { Program }\end{array}$ & $\begin{array}{l}\text { Tax credit of } \$ 1,000 \text { for every employee, for new hires that were previously } \\
\text { unemployed for a minimum of } 30 \text { days, and that remain employed after a 12- } \\
\text { month period at an average of } 36 \text { hours per week }\end{array}$ \\
\hline Georgia & $\begin{array}{l}\text { Quality Jobs } \\
\text { Credit }\end{array}$ & $\begin{array}{l}\text { Credit of } \$ 2,500-\$ 5,000 \text { per job per year, for up to five years, for companies } \\
\text { that create at least } 50 \text { jobs with salaries of at least } 110 \text { percent of the county } \\
\text { average; credit rises with ratio of salary to county average, from } \$ 2,500 \text { for } \\
110 \text { percent- } 120 \text { percent of county average to } \$ 5,000 \text { for } 200 \text { percent or more } \\
\text { of county average }\end{array}$ \\
\hline Illinois & $\begin{array}{l}\text { Small } \\
\text { Business Job } \\
\text { Creation Tax } \\
\text { Credit }\end{array}$ & $\begin{array}{l}\$ 2,500 \text { tax credit for employers with } 50 \text { or fewer total employees who hire } \\
\text { new, full-time Illinois employees, for new, full-time jobs sustained for at least } \\
\text { one year; job must pay at least } \$ 25,000 \text { per year }\end{array}$ \\
\hline Iowa & $\begin{array}{l}\text { New Jobs } \\
\text { Tax Credit }\end{array}$ & $\begin{array}{l}\text { Credit for businesses entering into jobs training agreement with a community } \\
\text { college, and increasing base employment level by at least } 10 \text { percent; credit is } \\
6 \text { percent qualifying wages }\end{array}$ \\
\hline Maryland & $\begin{array}{l}\text { Job Creation } \\
\text { and Recovery } \\
\text { Tax Credit }\end{array}$ & $\begin{array}{l}\text { Credit up to } \$ 5,000 \text { for hiring individuals receiving Unemployment Insurance } \\
\text { benefits or who exhausted benefits in the previous } 12 \text { months and are not } \\
\text { working full time immediately preceding the date of hire; hiring into full-time } \\
\text { positions that are new or have been vacant for at least } 6 \text { months }\end{array}$ \\
\hline $\begin{array}{l}\text { Rhode } \\
\text { Island }\end{array}$ & $\begin{array}{l}\text { Hiring of } \\
\text { Unemployed } \\
\text { or Low- } \\
\text { Income } \\
\text { Residents }\end{array}$ & $\begin{array}{l}\text { Credit of } 40 \text { percent (up to maximum of } \$ 2,400 \text { ) for newly-hired state } \\
\text { residents previously unemployed or receiving public assistance; worker must } \\
\text { have been unemployed for a period of at least } 26 \text { consecutive weeks prior to } \\
\text { hire and either received public assistance for at least } 1 \text { year or have received } \\
\text { unemployment benefits at any time during the prior } 52 \text { weeks }\end{array}$ \\
\hline $\begin{array}{l}\text { West } \\
\text { Virginia }\end{array}$ & $\begin{array}{l}\text { Corporate } \\
\text { Headquarters } \\
\text { Credit }\end{array}$ & $\begin{array}{l}\text { Tax credit offsetting up to } 100 \text { percent of tax liability for companies that } \\
\text { relocate corporate headquarters to West Virginia and create } 15 \text { new jobs } \\
\text { (including relocated employees) }\end{array}$ \\
\hline
\end{tabular}

Notes: State examples are restricted to direct and broad-based hiring credits. Many states also have versions of enterprise zone programs, and some have hiring credits targeting the disadvantaged. 
Table 2: The Federal Earned Income Tax Credit and Selected State Programs, 2010

\begin{tabular}{|c|c|c|c|c|}
\hline \multicolumn{5}{|c|}{ A. Federal EITC (2010) } \\
\hline & 3 or more children & 2 children & 1 child & No children \\
\hline $\begin{array}{l}\text { Phase-in rate (percent subsidy to } \\
\text { earnings) }\end{array}$ & 45 & 40 & 34 & 7.65 \\
\hline Maximum credit & $\$ 5,666$ & $\$ 5,036$ & $\$ 3,050$ & $\$ 457$ \\
\hline $\begin{array}{l}\text { Income at which maximum credit } \\
\text { reached }\end{array}$ & $\$ 12,590$ & $\$ 12,590$ & $\$ 8,970$ & $\$ 5,980$ \\
\hline Income at which phase-out begins & $\$ 16,450$ & $\$ 16,450$ & $\$ 16,450$ & $\$ 7,480$ \\
\hline $\begin{array}{l}\text { Phase-out rate (percent reduction in } \\
\text { credit with additional earnings) }\end{array}$ & 21.06 & 21.06 & 15.98 & 7.65 \\
\hline Income at which credit eliminated & $\$ 43,352$ & $\$ 40,363$ & $\$ 35,535$ & $\$ 13,460$ \\
\hline \multicolumn{5}{|c|}{ B. State EITC's (2009) } \\
\hline & \multicolumn{4}{|c|}{ Percent of federal EITC } \\
\hline Delaware & \multicolumn{4}{|c|}{20 percent (non-refundable) } \\
\hline District of Columbia & \multicolumn{4}{|c|}{40 percent } \\
\hline Illinois & \multicolumn{4}{|c|}{5 percent } \\
\hline Indiana & \multicolumn{4}{|c|}{9 percent } \\
\hline Iowa & \multicolumn{4}{|c|}{7 percent } \\
\hline Kansas & \multicolumn{4}{|c|}{17 percent } \\
\hline Louisiana & \multicolumn{4}{|c|}{3.5 percent } \\
\hline Maine & \multicolumn{4}{|c|}{5 percent (up to $\$ 125$ refundable for joint filers) } \\
\hline Maryland & \multicolumn{4}{|c|}{50 percent non-refundable or 25 percent refundable } \\
\hline Massachusetts & \multicolumn{4}{|c|}{15 percent } \\
\hline Michigan & \multicolumn{4}{|c|}{20 percent } \\
\hline Minnesota & \multicolumn{4}{|c|}{ Varies with number of children, averages 33 percent } \\
\hline Nebraska & \multicolumn{4}{|c|}{10 percent } \\
\hline New Jersey & \multicolumn{4}{|c|}{25 percent } \\
\hline New Mexico & \multicolumn{4}{|c|}{10 percent } \\
\hline New York & \multicolumn{4}{|c|}{30 percent } \\
\hline North Carolina & \multicolumn{4}{|c|}{5 percent } \\
\hline Oklahoma & \multicolumn{4}{|c|}{5 percent } \\
\hline Oregon & \multicolumn{4}{|c|}{6 percent } \\
\hline Rhode Island & \multicolumn{4}{|c|}{$\begin{array}{c}25 \text { percent (non-refundable, but } 15 \text { percent of amount is } \\
\text { refundable) }\end{array}$} \\
\hline Vermont & \multicolumn{4}{|c|}{32 percent } \\
\hline Virginia & \multicolumn{4}{|c|}{20 percent (non-refundable) } \\
\hline Wisconsin & \multicolumn{4}{|c|}{$\begin{array}{c}4 \text { percent ( } 1 \text { child), } 14 \text { percent ( } 2 \text { children), } 43 \text { percent ( } 3 \text { or more } \\
\text { children) }\end{array}$} \\
\hline
\end{tabular}

Notes: The separate credit for 3 or more children is a temporary measure for the 2009 and 2010 tax years, after which the numbers for families with 2 children apply to families with 2 or more children. Numbers shown are for those filing singly. Phase-in and phase-out rates are the same for those filing jointly; incomes at which phase-out rate begins and incomes at which the credit is eliminated are higher by $\$ 5,010$ for those filing jointly. In Panel B, if not noted state EITC is refundable. The dollar amounts are indexed.

Sources: Tax Policy Center, Urban Institute and Brookings Institution (http://www.taxpolicycenter.org/briefing-book/key-elements/family/eitc.cfm, viewed July 20, 2010); State EITC Online Resource Center (http://www.stateeitc.com/map/index.asp, viewed July 20, 2010). 
Table 3: Summary of Conclusions on Using Hiring Credits to Spur Job Creation

\begin{tabular}{|c|c|}
\hline & Hiring credits \\
\hline Predicted effects & - Increases employment \\
\hline $\begin{array}{l}\text { Evidence on } \\
\text { effectiveness }\end{array}$ & $\begin{array}{l}\text { - Ineffective when targeted at disadvantaged } \\
\text { - More effective when targeted at unemployed for net job } \\
\text { creation }\end{array}$ \\
\hline $\begin{array}{l}\text { Costs per job } \\
\text { created }\end{array}$ & $\begin{array}{l}\text { - Approximately } \$ 9,100-\$ 75,000 \text {, and more likely in lower } \\
\text { half of this range }\end{array}$ \\
\hline $\begin{array}{l}\text { Distributional } \\
\text { effects }\end{array}$ & - Generally do not target low-income families well \\
\hline $\begin{array}{l}\text { Effectiveness in } \\
\text { countering Great } \\
\text { Recession }\end{array}$ & $\begin{array}{l}\text { - Targeting of unemployed generally entails less stigmatization } \\
\text { - Smaller windfalls and lower administrative costs because of } \\
\text { low job growth } \\
\text { - Labor supply is highly elastic } \\
\text { - Better-than-usual distributional effects because of adverse } \\
\text { impact of recession on men }\end{array}$ \\
\hline $\begin{array}{l}\text { Increasing } \\
\text { effectiveness of } \\
\text { short-term policy }\end{array}$ & $\begin{array}{l}\text { - Make credits non-categorical } \\
\text { - Make credits explicitly temporary } \\
\text { - Do not restrict credits to small employers } \\
\text { - Incentivize employment and not hours } \\
\text { - Design and monitor to avoid diffusion into general tax relief }\end{array}$ \\
\hline
\end{tabular}

